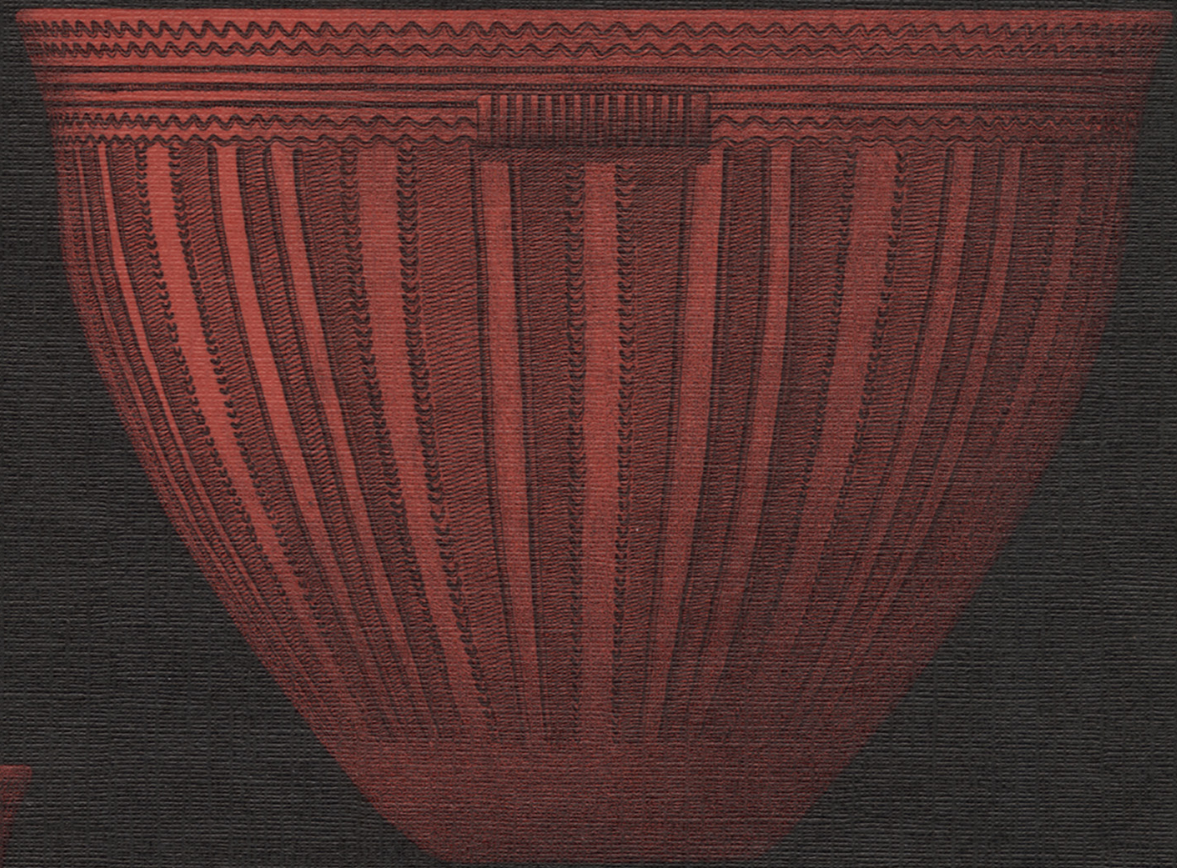

\title{
KUNL 2000
}


KUML 2000 


\section{KUML 2000}

\section{Årbog for Jysk Arkæologisk Selskab}

With summaries in English

I kommission hos Aarhus Universitetsforlag 
Redaktion: Jesper Laursen

Omslag: Louise Hilmar

Korrektur: Anne Lise Hansen

Tilrettelagning: Narayana Press

Tryk: Narayana Press

Skrift: Bembo 12/13

Papir: 115 g Arctic Silk

Copyright (C) 2000 Jysk Arkacologisk Selskab

ISBN 87-88415-08-2

ISSN 0454-6245 


\section{Indhold/Contents}

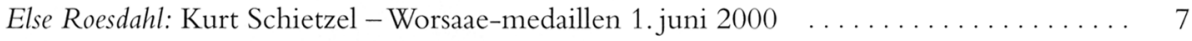

Kurt Schietzel - the Worsaae Medal 1st of June $2000 \ldots \ldots \ldots$. . . . . . . . 9

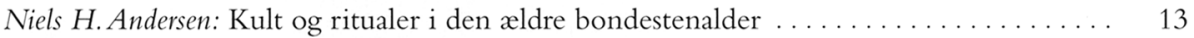

Cult and Rituals in the TRB-Culture $\ldots \ldots \ldots \ldots \ldots \ldots \ldots \ldots \ldots \ldots \ldots$

Keld Møller-Hansen og Henrik Høier: Næs - en vikingebebyggelse

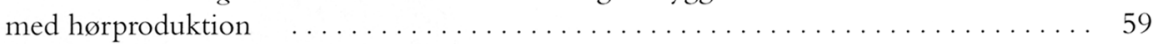

Næs - a Viking Age settlement with flax production $\ldots \ldots \ldots \ldots \ldots \ldots \ldots \ldots$

Martin Borring Olesen: Trelleborg eller ej?

- om den skånske trelleborgs tilknytning til de danske ringborge $\ldots \ldots \ldots \ldots \ldots$. . 91

A Viking fortress? On the possible connection between the Trelleborg

fortress in Scania and the Danish Viking fortresses . . . . . . . . . . . . . . . . . 109

Ole Schiøring: En middelalderby forandrer sig

- hovedresultater fra ti års udgravninger i Horsens . . . . . . . . . . . . . . . . 113

The change of a medieval town

- the main results from a ten-year excavation campaign in Horsens . . . . . . . . . . 147

Helle Henningsen: Middelalder i Fjand $\ldots \ldots \ldots \ldots \ldots \ldots \ldots \ldots \ldots \ldots \ldots \ldots \ldots \ldots \ldots \ldots$

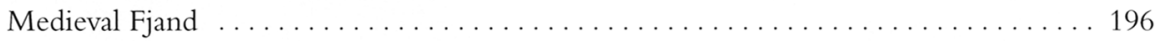

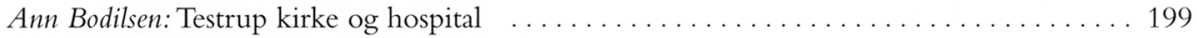

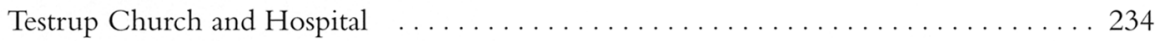

Hanne Dahlerup Koch: Middelalderens gader . . . . . . . . . . . . . . . . . . 239

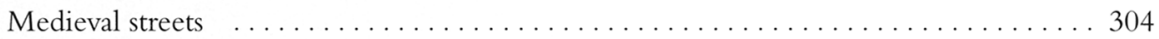

Lis Romer Trier: Lodning med sølvsalte

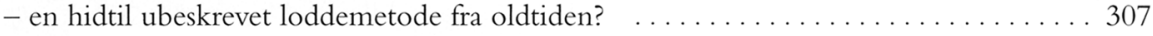

Soldering using nitrate of silver

- A previously undescribed prehistoric soldering method? . . . . . . . . . . . 312

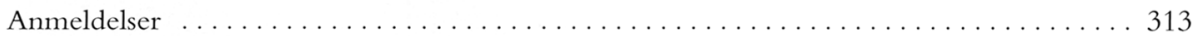

Jysk Arkæologisk Selskab 1998 . . . . . . . . . . . . . . . . . . . . . . . . 367

Jysk Arkæologisk Selskabs skrifter $\ldots \ldots \ldots \ldots \ldots \ldots \ldots \ldots \ldots \ldots \ldots \ldots \ldots \ldots \ldots$ 


\title{
Testrup kirke og hospital
}

\author{
Af ANn Bodilsen
}

Traditionelt regner man med, at der fandtes tre typer af hospitaler i middelalderens Danmark, nemlig klosterhospitaler, helligåndshuse og Skt. Jørgensgårde. ${ }^{1}$ Alle tre typer blev drevet i et klosterlignende regi, og det er dermed tydeligt, at brugen af hospitaler er knyttet sammen med kristendommens indførelse i Danmark og de forskellige klosterbevægelsers indtog i landet. I Viborg området har vi imidlertid kendskab til to hospitaler, som tilsyneladende falder udenfor denne opdeling. Det drejer sig, udover Testrup hospital, som er emne for denne artikel, om hospitalet ved Vor Frue Kirke i Karup.Valfarten til helligkilden og den grædende Madonna i Karup er velkendt i litteraturen, ${ }^{2}$ mens Testrup er ukendt for de fleste.

Testrup kirke fremstår i dag som en mindre langhuskirke og ligger på en bakketop nord for Testrupgård vest for landsbyen Testrup i Himmerland. I dag er Testrup en stille landsby beliggende langt fra alfarvej, men i senmiddelalderen var stedet et velbesøgt valfartssted. Testrup lå centralt $\mathrm{i}$ Viborg stift, og det nordgående Hærvejsstrøg fraViborg mod Aalborg passerede forbi (fig. 1). ${ }^{3}$ Her lå i senmiddelalderen en stor gotisk korskirke med tilbygget hospital, og ifølge traditionen havde bispen en gård i området som centrum for den kirkelige administration, i nærheden lå en helligkilde, og der blev afholdt årlige markeder. Både kirken og hospitalet kendes fra de skriftlige kilder, men der er intet i kilderne, som fortæller om forudsætningerne for hospitalsbyggeriet. Med den centrale beliggenhed i stiftet og dermed også for Viborgbispens administration, har stedet naturligt haft bispens bevågenhed. Placeringen ved Hærvejen har ligeledes medvirket til at give Testrup en velegnet beliggenhed for hospitals- og ikke mindst herbergsfunktion. ${ }^{4} \mathrm{Vi}$ ved, at hospitalet i Testrup blev styret af en forstander, som samtidig var præst for Testrup og Gislum pastorat, ${ }^{5}$ og vi må antage, at hospitalets økonomiske grundlag hovedsageligt var baseret på indtægter fra Testrupgård jordegods. Hertil kom sandsynligvis bidrag fra den nærliggende Skt. Sørens kilde, hvortil der valfartedes, ligesom der blev holdt årlige markeder. Hvor stor en rolle helligkilden har spillet, kan vi imidlertid kun gisne om, idet der ikke kendes nogen middelalderlige kilder, som beretter om dens betydning, og at stedet skulle have haft nogen større betydning som valfartssted, kan heller ikke bekræftes via de skriftlige kilder. 


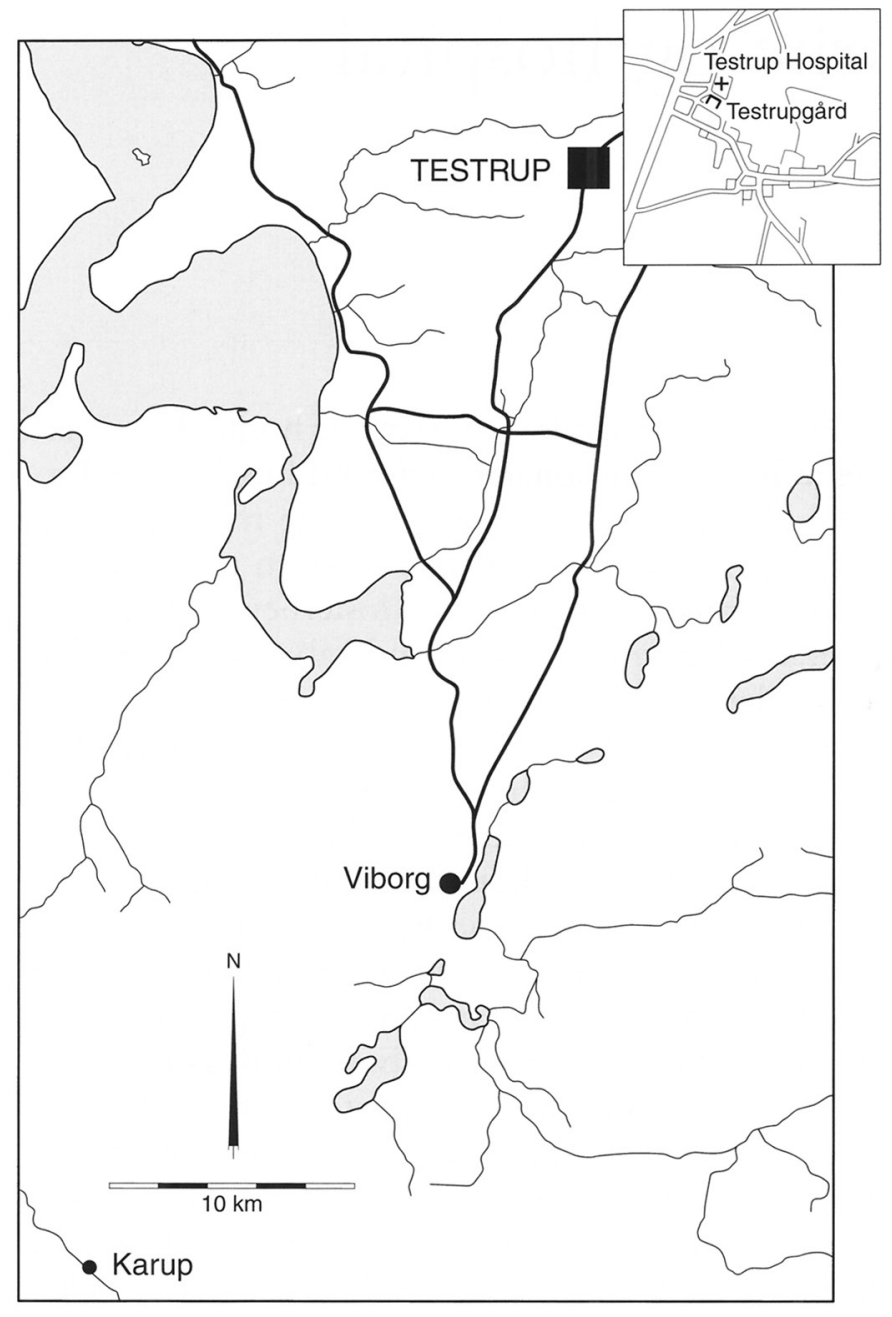

Fig. 1. Kort over Viborg området med Testrup, Viborg, Karup og Hærvejen indtegnet. Streg: Sven Kaae.

This map of the $\mathrm{Vi}$ borg area shows $\mathrm{Te}$ strup, Viborg, Karup, and the Iron Age and the medieval road between Viborg and Aalborg. Drawn by Sven Kaae.

\section{Testrup i de skriftlige kilder}

I litteraturen nævnes det, at Testrupgård første gang bliver omtalt i de skriftlige kilder i 1399, hvor Jacob Hemmingsen skriver sig til Testrup, og det antages derfor, at Testrupgård på daværende tidspunkt må have været en adelig sædegård. ${ }^{6}$ Ved læsning af den skriftlige kilde er det imidlertid klart, at der er tale om en forveksling med Testrup i Ringsted herred, 
Sorø amt. ${ }^{7}$ Dermed bliver den første skriftlige omtale af Testrup i 1432, hvor bisp Herman af Viborg siges at oprette et hospital i Testrup. Dokumentet eksisterer tilsyneladende ikke længere, men kendes fra omtale i Pontoppidans Danske Atlas. ${ }^{8}$ Testrups historie i de skriftlige kilder begynder altså med oprettelsen af hospitalet, mens stedets tidligere historie ikke kendes fra de skriftlige kilder. Næste gang Testrup optræder i de skriftlige kilder er antagelig i 1439, hvor kirken indvies af bisp Torlav til Skt. Katarina - også kaldet Karen. ${ }^{9}$

Andre steder nævnes det, at kirken tillige var viet til Skt. Søren. ${ }^{10} \mathrm{Mu}-$ ligvis skyldes det omtalen af kirkens præst fra 1511-1535, Chresten Nielsen Helgesen, som siges at have været tidligere munk og Skt. Sørens præst i Rye. ${ }^{11}$ Herfra stammer måske også den fejlagtige antagelse, at der har været et munkekloster i Testrup. Det er Kristen Sørensen Testrup, der første gang omtaler stedet som et munkekloster, men allerede Pontoppidan gør opmærksom på, at der må være tale om en fejltagelse. ${ }^{12}$ Det kan imidlertid også være den nærliggende helligkilde Skt. Søren, som har ført til den antagelse, at kirken var viet til Skt. Søren. Endelig foreligger der den mulighed, at selve hospitalet i lighed med kilden var viet til Skt. Søren. ${ }^{13}$

Ved reformationen blev hospitalet inddraget under Kronen, som i første omgang lod hospitalet bestå.

I et brev af 7. februar 1545, der var baseret på Hans Tausens kritiske redegørelse, skænker Christian den Tredje imidlertid Testrupgård med jorder tilViborg hospital stiftet i 1541, og hospitalet i Testrup bliver nedlagt. ${ }^{14}$ Fra da af begynder kirken sandsynligvis langsomt at forfalde. I $1567 \mathrm{mi}-$ ster kirken sin største klokke, idet den blev givet til domkirken i Viborg, hvis klokker var smeltet ved branden samme år. ${ }^{15}$ I 1699 solgte Viborg Hospital Testrupgård til en privatmand, og siden har gården været på private hænder.

Det antages almindeligvis, at hospitalet og kirkens vestende er blevet revet ned i 1748, idet det er dette årstal, der kan læses på kirkens nuværende vestgavl (fig. 2). I biskop Søren Lintrups visitatsbog omtales kirken d. 27. juni 1722 som velrepareret og vedligeholdt, mens hospitalet ikke nævnes. I Pontoppidans Danske Atlas fra 1768 omtales tårnet samt en del af kirken imidlertid som nedfalden. ${ }^{16}$ Ruinerne kunne dog endnu på dette tidspunkt ses vest for kirken. Det er derfor rimeligt at antage, at 1748 betegner nedrivningen af kirkens vestende; hvorvidt det også angår hospitalsbygningen er uvist. 


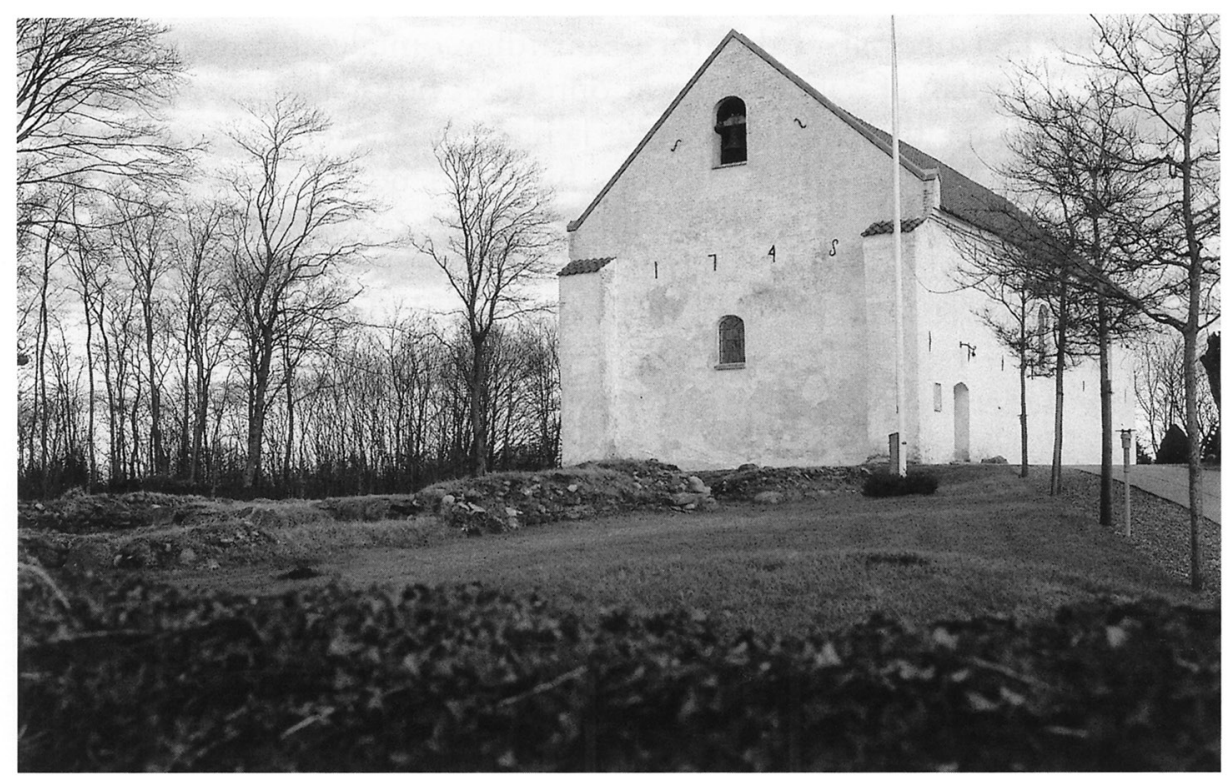

Fig. 2. Testrup kirke som den tager sig ud i dag med ruinen af hospitalsbygningen ved vestenden. På kirkens vestgavl ses årstallet 1748, som antages at være det år, hvor kirkens vestende og muligvis også hospitalet blev revet ned. Foto: Betty Laustsen.

Testrup Church as it looks today, with the ruin of the hospital to the west. The western gable of the church bears the year 1748 - supposedly the year when the western end and perhaps also the hospital was pulled down. Photo: Betty Laustsen.

\section{Arkæologiske undersøgelser ved Testrup}

Arkæologisk set er Testrup kirke og hospital forholdsvis velkendt. I 1980 undersøgte Nationalmuseet kirken i forbindelse med en restaurering, og der blev ved den lejlighed også gravet flere steder i og ved kirken. ${ }^{17} \mathrm{Di}-$ rekte inspireret af disse undersøgelser blev der fra 1981-83 iværksat en udgravningskampagne, hvor den resterende del af kirken samt selve hospitalsområdet blev undersøgt (fig. 3). Udgravningerne blev finansieret som et beskæftigelsesprojekt for Ålestrup kommune, hvorViborg amt betalte projektlederen, mens kommunen betalte materialer samt arbejdskraft. I alle årene var landskabsarkitekt Niels Junggren Have den daglige leder for et skiftende antal arbejdsledige. ${ }^{18}$ Formålet med undersøgelserne lå hovedsageligt $\mathrm{i}$ at fjerne den brokbanke, som lå ud for kirkens nuværende vestgavl, for at fastslå anlægsudformningen i den senmiddelalderlige hospitalsepoke. Fra lokal side så man desuden gerne, at der blev etableret en "ruinpark". 


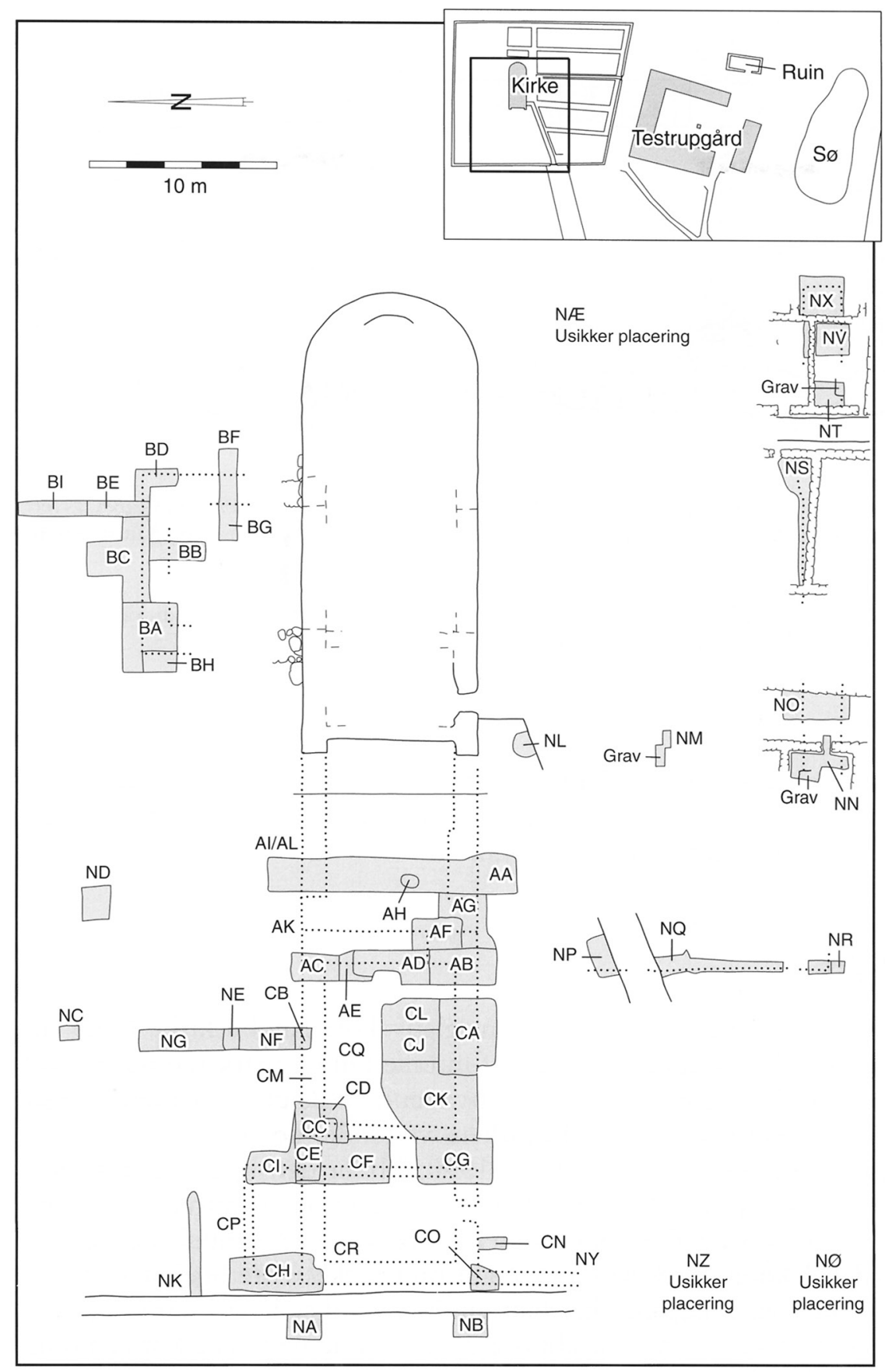

Fig. 3. Oversigt over de felter som blev udgravet i løbet af årene 1981-83. Øverst ses kirkens placering i forhold til det nuværende Testrupgård samt ruinen af Testrup stenhus. Streg: Sven Kaae.

A survey of the areas excavated in 1981-83. The situation of the church, the present Testrupgard, and the ruined Testrup Stenhus are shown at the top. Drawn by Sven Kaae. 


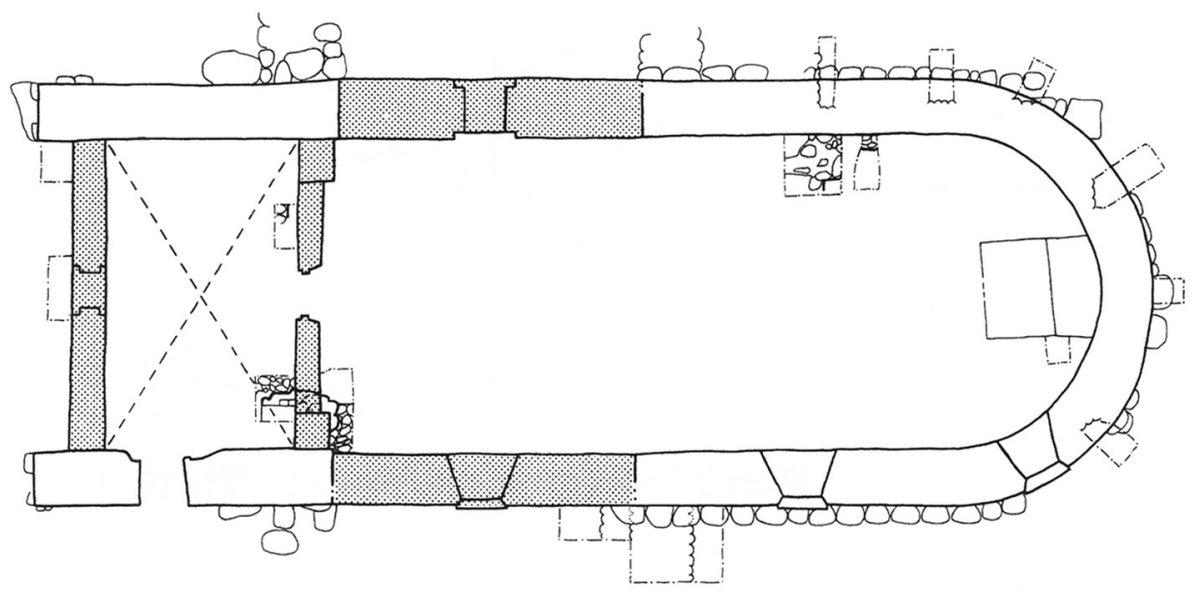

Fig. 4. Den nuværende kirke med Nationalmuseets udgravningsfelter fra 1980 indtegnet. Nyere tilmuringer og skillevægge er markeret med prikket signatur. (Efter Als Hansen og Aaman Sørensen 1981).

The present church with the areas excavated by the National Museum in 1980 indicated. Late alterations have a dotted signature. From Als Hansen og Aaman Sørensen 1981, p. 73.

Dokumentationsmaterialet består af udgravningslederens notater, fotoog fundlister samt enkelte tegninger. Af stor værdi er et betydeligt antal fotografier taget under udgravningen.

\section{Kirken}

Testrup kirke fremstår i dag som en relativ kort langhuskirke (23,5 m) med halvrund østafslutning bygget af munkesten og marksten på en sokkel af romanske granitkvadre. Den nuværende indgang til kirken foregår gennem en overhvælvet forhal i kirkens vestende (fig. 4).

Nationalmuseets undersøgelser i $1980,{ }^{19}$ hvor den løse vægpuds blev banket af, viste, at hele kirken tidligere har været overhvælvet, og nederst på de bevarede vægribber kunne der ses rester af en simpel rød og sort kalkmalet dekoration. Afbankningen af murværket viste ligeledes, at kirken, ganske som i dag, kun har haft vinduer mod syd, og i korsskæringsfaget gav de store rundbuede åbninger ud mod de nedrevne korsarme sig tydeligt til kende.

Ved undersøgelser i gulvet blev det oprindelige munkestensgulv påvist, ligesom både resterne af højalteret og et sidealter blev påvist. De arkæologiske undersøgelser viste endvidere, at der under den nuværende kirke findes resterne af en ældre og langt mindre kirke. Der er tale om 
Fig. 5. I indkørslen til Testrupgård findes et stendige med en hel del granitkvadre i. Kvadrene antages at stamme fra den romanske kvaderstenskirke, som blev revet ned forud for byggeriet af den gotiske kirke og hospitalet. Foto: Betty Laustsen.

A stone wall with numerous granite ashlars is situated by the drive leading to Testrupgård. The ashlars are thought to derive from the Romanesque ashlar church, which was demolished prior to the erection of the Gothic church and the hospital. Photo: Betty Laustsen.

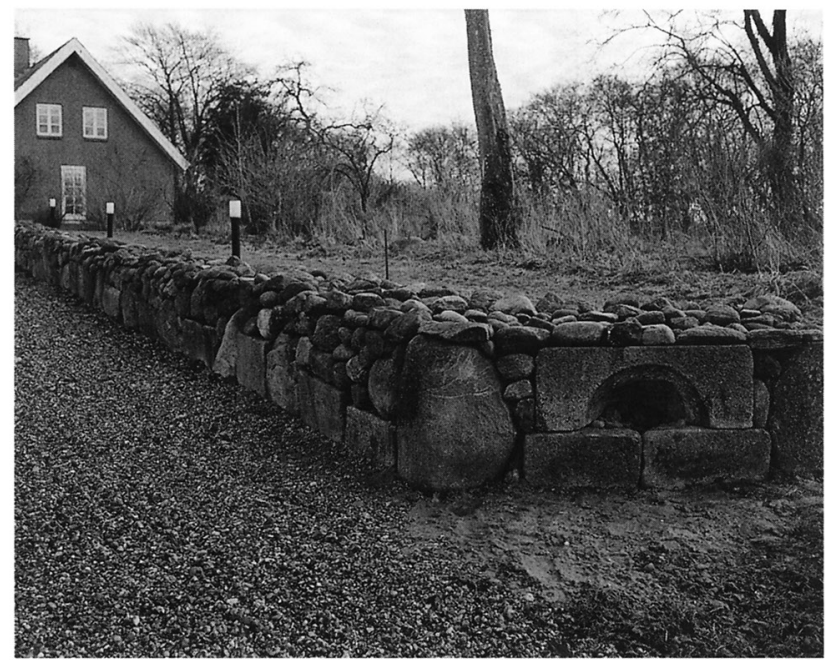

fundamenterne til en ganske almindelig romansk landsbykirke bestående af kor og skib. De mange genanvendte kvadre i den nuværende kirkes sokkel samt de romanske granitkvadre, der findes på Testrupgård, må stamme fra den gamle kirke, som både i udseende og størrelse har lignet egnens øvrige kvaderstenskirker (fig. 5).

Det var altså resultaterne af disse undersøgelser, som førte til de videre undersøgelser i 1981-1983.

\section{Kirkens vestende}

Udgravningen af kirkens vestende forløb over alle tre år, således at hele kirkens vestende på nær de to meter nærmest kirkens nuværende vestgavl var under udgravning (fig. 6).

Udgravningerne viste, at kirken oprindeligt har været ca. $11 \mathrm{~m}$ længere, hvoraf de 7 meter længst mod vest har udgjort et tårn. Kirkemurenes fundamenter var bevaret overalt, men mod nord var fundamentet flere steder plyndret for de store sten. Tårnmurenes fundamenter var bredere end kirkemurenes, idet de var ca. $175 \mathrm{~cm}$ brede, mens de øvrige fundamenter kun var ca. $150 \mathrm{~cm}$ brede. Fundamenterne var sat af kampesten af forskellig størrelse - med mørtel imellem.

Selve muren var en kassemur hovedsagelig bestående af munkesten med fyld af teglbrokker, kampesten og mørtel. Enkelte steder var der bevaret rester af murværket, men de fleste steder var kun murkernen samt aftrykket af det nederste skifte bevaret. Murværket var bedst bevaret mod syd, hvor det var muligt at måle murbredden til $116 \mathrm{~cm}$. Mu- 


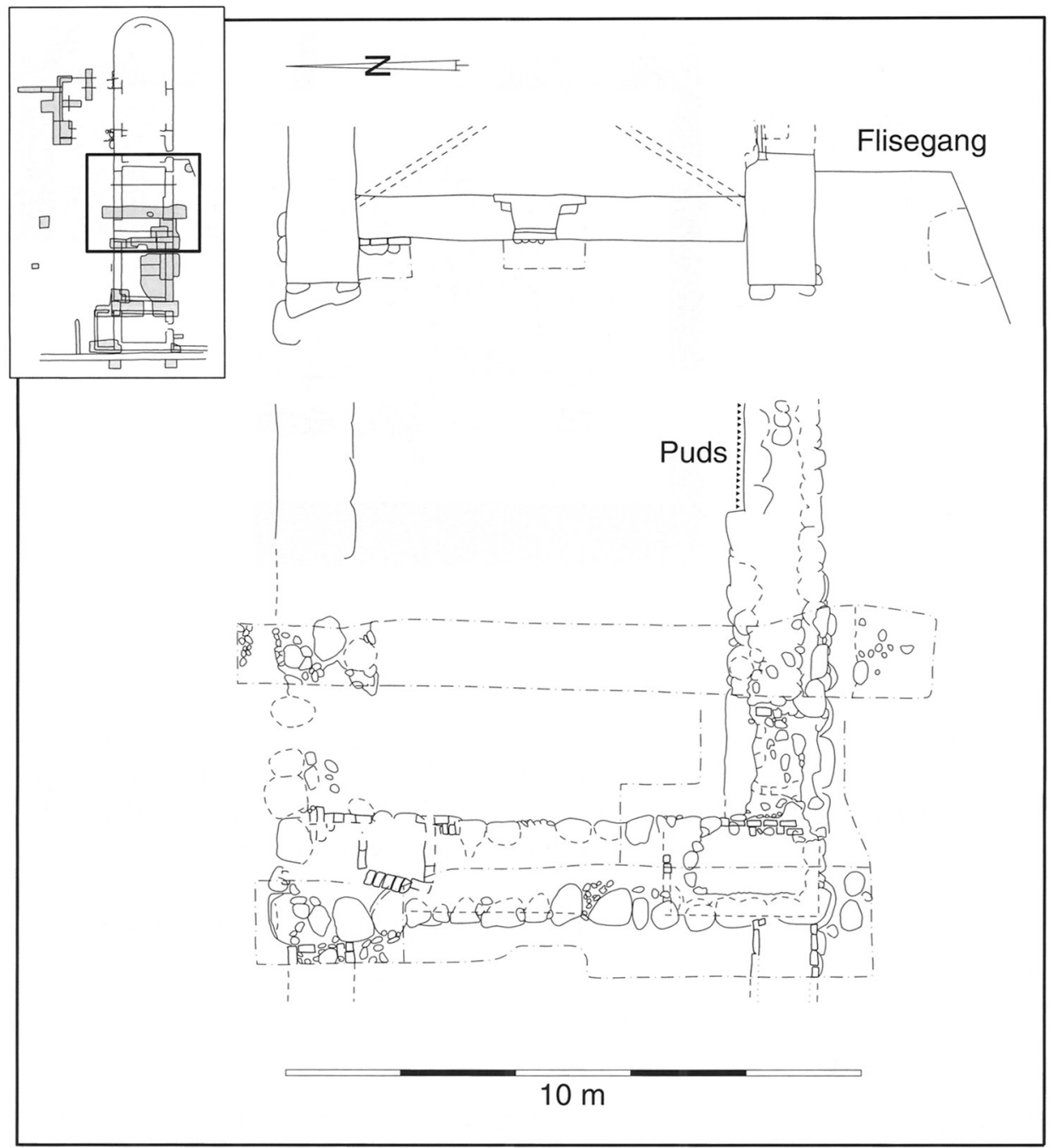

Fig. 6. Plantegning af udgravningen af kirkens vestende. Opmåling: Niels Junggren Have; streg: Sven Kaae.

A survey of the excavation of the western end of the church. Measured by Niels Junggren Have. Drawn by Sven Kaae.

ren i vestgavlen synes dog at have været en del bredere, ca. 150-160 cm. Desuden har i hvert fald det nederste skifte af murværket udvendigt $\mathrm{i}$ vestgavlen været sat af kvadersten. Det kunne ses som aftryk i fundamentet samt i murkernen (fig. 7). Murene har stået kalket både udvendigt og indvendigt. 
Fig. 7. Parti af kirkens vestgavl. Der ses tydelige aftryk af kvadersten i murkernen og på fundamentsstenene. Til højre i billedet ses munkestensmuren fra hospitalsbygningen. Foto: Niels Junggren Have.

Part of the western gable of the church. The wall core and the foundation show distinct imprints of ashlars. The brick wall of the hospital is seen to the right. Photo: Niels Junggren Have.

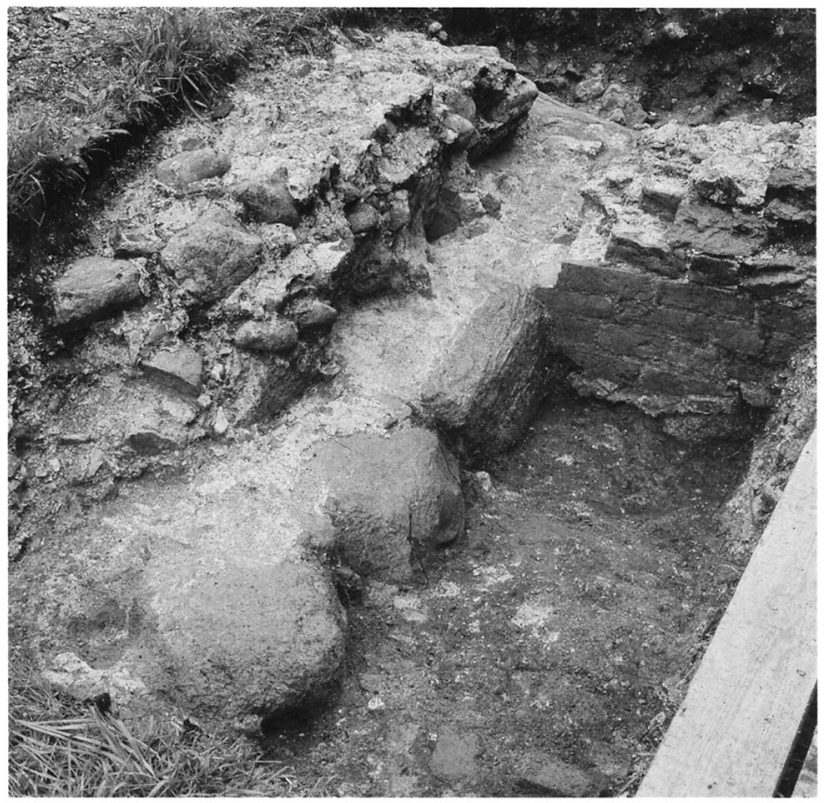

Fig. 8. Kirkens vestende under udgravning. Bagest $\mathrm{i}$ billedet ses døren i kirkens sydmur at flugte med vestgavlens inderside. Der var bevaret store partier af et munkestensgulv bestånde af hele og halve munkesten. Foto: Niels Junggren Have.

The western end of the church during excavation. The door in the south wall of the church is seen at the back, flushing with the inner gable wall. Large areas of the original wall built of bricks and half bricks are preserved. Photo: Niels Junggren Have.

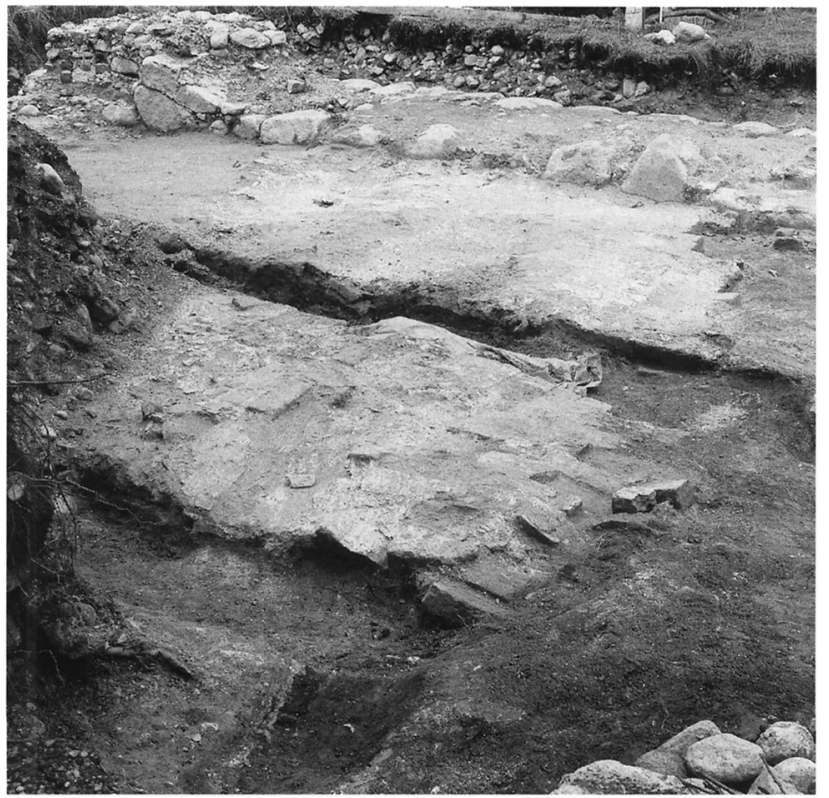

Der er registreret tre døråbninger i kirkens vestende - en dør i henholdsvis nord og syd helt op til vestgavlen samt en dør i vestgavlen.

Nord- og syddørene har været $175 \mathrm{~cm}$ brede, og dørenes vestside har flugtet med indersiden af vestgavlen (fig. 8). Begge døråbninger må betragtes som oprindelige, og adgangen til kirken er altså sket via tårnet. 


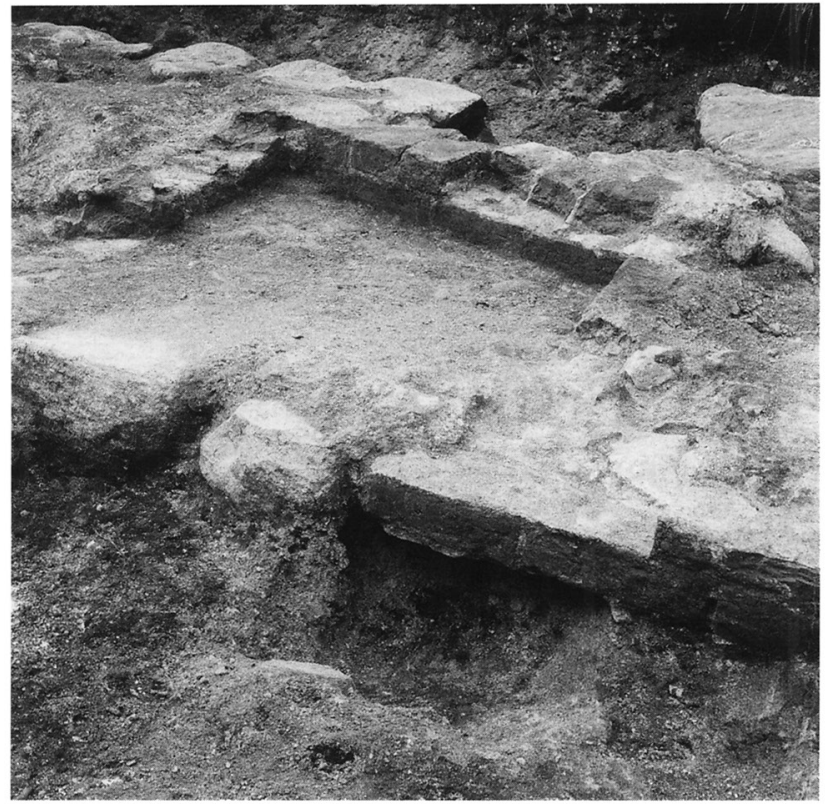

Fig. 9. I tårnets NV-hjørne, som er en anelse udvidet, ses resterne af det nederste trin af en 1 meter bred vindeltrappe, som har løbet inde i den knap to meter tykke mur. Foto: Niels Junggren Have.

In the NW-corner of the tower are the remains of the first step from a one metre wide spiral staircase that ran inside the wall, which was almost two metres thick. Photo: Niels Junggren Have.

Døråbningen i kirkens vestgavl kunne erkendes ved bevarede munkesten ca. $270 \mathrm{~cm}$ nord for kirkens sydvesthjørne. Det var derimod vanskeligere at erkende dørens nordre vange, men på grundlag af svage kalkspor på fundamentsstenene antages døren at have haft omtrent samme bredde som de to øvrige døre. Det kan ikke med sikkerhed afgøres, om døren i vestgavlen er oprindelig. Døråbningen har kun en funktion set i relation til det vest for tårnet liggende hospital, men da de to bygningers tidsmæssige forhold til hinanden historisk-kildemæssigt set er dårligt belyst, er det uvist, om døren er en oprindelig detalje.

I tårnets NV-hjørne, som er en anelse udvidet, er der bevaret rester af det nederste trin af en 1 meter bred vindeltrappe, som har løbet inde i den knap to meter tykke mur. Indgangen til trappen ses umiddelbart indenfor nordmuren (fig. 9). Trappen har ført op til tårnets øvrige etager.

Overgangen mellem kirke- og tårnrum markeres ved, at fundamenterne i kirkerummet er ca. $25 \mathrm{~cm}$ smallere end tårnrummets. På dette sted ved kirkens nordmur er der desuden bevaret rester af den pudsede murflade, og her slår den et vinkelret knæk ud i rummet; også sydmuren viste tegn på dette knæk. Det tolkes som begyndelsen til en bue mellem kirkeog tårnrum. Det anses for usandsynligt, at tårnet har været lukket af en massiv mur, idet der ikke er fundet rester efter fundamenterne til en sådan mur, og da indgangen til kirken er sket via tårnet, synes det mest sandsynligt, at de to bygningselementer har udgjort et hele. 
Fig. 10. To af de tre blygruber, som blev udgravet i kirkens vestende. Den ildpåvirkede lerkappe fremstår tydeligst på blygruben bagest i billedet. Foto: Niels Junggren Have.

Two of the three lead pits excavated in the western end of the church. The burnt clay cap of the pit at the back is clearly visible. Photo: Niels Junggren Have.

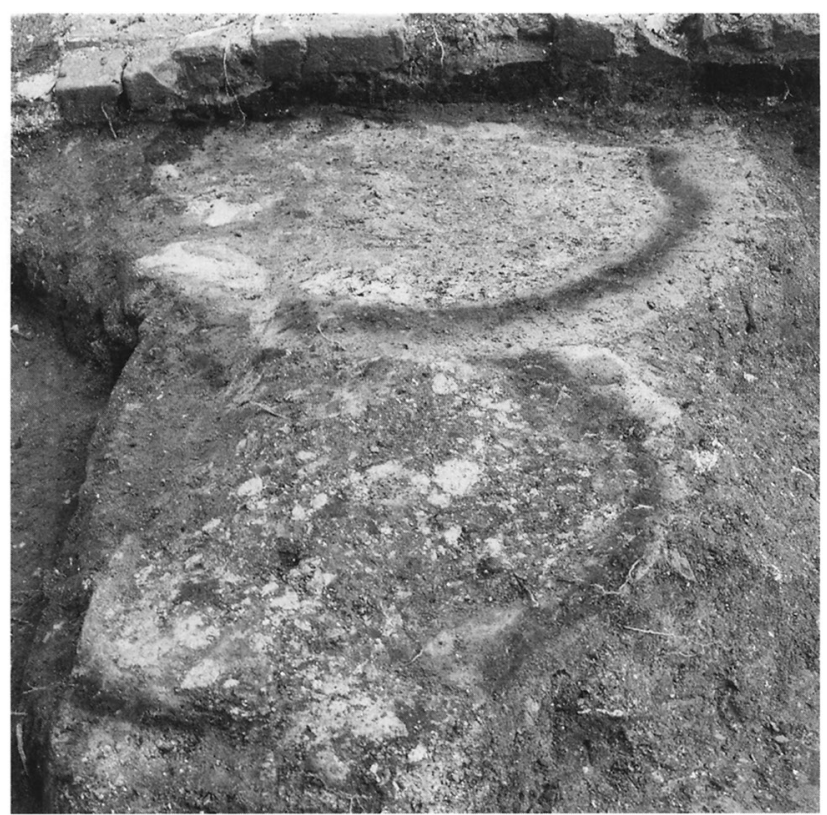

Over store dele af kirkens vestende er der bevaret rester af et munkestensgulv. Munkestensgulvet samt det gule sand, det er nedlagt i, korresponderer meget fint med pudslag iagttaget forskellige steder langs muren antydende et gulvniveau. Munkestensgulvet var lagt af hele og halve munkesten, og flere steder var de meget smuldrende. Gulvniveauet svarer til det jævnt øst-vest faldende gulv konstateret inde i kirken. Udenfor kirken, omtrent i niveau med kirkegulvet, blev der iagttaget spredte rester af en pigstensbrolægning.

Under munkestensgulvet blev der registreret tre blygruber. Den ene lå indenfor syddøren, mens de to øvrige var placeret umiddelbart indenfor norddøren (fig. 10). Placeringen af blygruberne svarer nøje til, hvad der er registreret $i$ andre middelalderkirker. Alle blygruber var opbygget som en grydeformet lerkappe og er tydeligt ildpåvirkede. De varierer i størrelse fra $80-130 \mathrm{~cm}$.

Om blygruberne skal tages som udtryk for, at kirken har været beklædt med blytag, er vanskeligt at afgøre. I de massive nedbrydningslag, som lå henover fundamenterne, blev der fundet adskillige tagtegl, de såkaldte munke-nonner, således at man må formode, at kirken, da den blev revet ned, har haft tegltag. Om kirken tidligere har haft blytag, som senere er blevet smeltet om, eller om blygruberne har været anvendt til fremstilling af $\mathrm{fx}$ vinduesblysprosser, kan således ikke afgøres. ${ }^{20}$ 


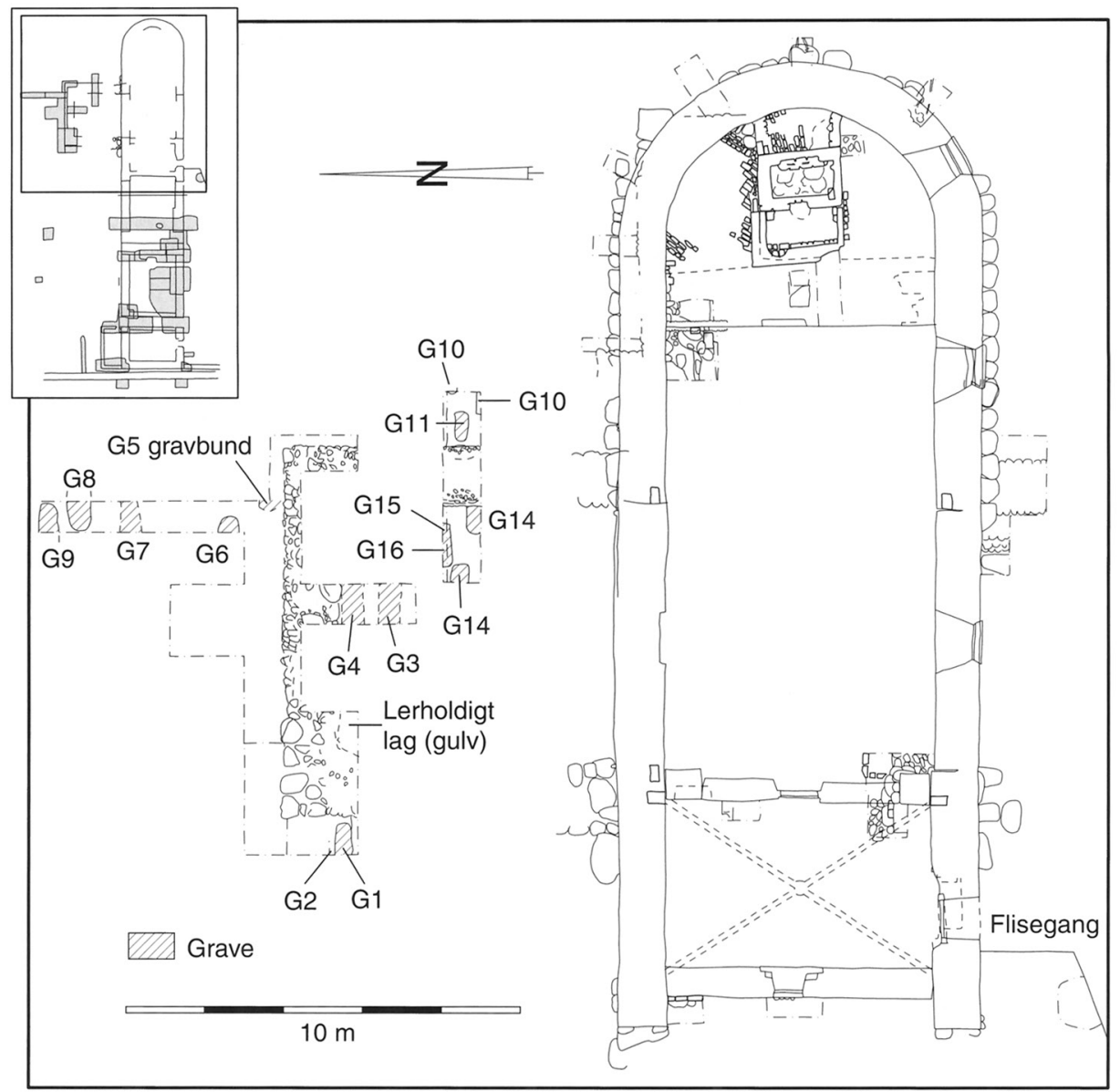

Fig. 11. Plantegning af udgravningen af nordre korsarm. Opmåling: Niels Junggren Have; streg: Sven Kaae.

A survey of the excavations in the northern transept. Measured by Niels Junggren Have. Drawn by Sven Kaae.

\section{Nordre korsarm}

I 1981 blev kirkens nordre korsarm delvist udgravet (fig. 11). Allerede ved kirkerestaureringen i 1980 registrerede man en del af korsarmens fundamenter i umiddelbar tilknytning til kirkens nordmur.

Der var i alle felterne bevaret rester af korsarmens fundamenter, men ingen steder var der bevaret rester af murværk. Fundamenterne havde en bredde på mellem 150-160 cm, hvilket er det samme som for kirkens øvrige fundamenter, og det antages derfor, at murene har haft samme bredde som den øvrige del af kirken, ca. $115 \mathrm{~cm}$. Fundamenterne var sat i en 
grøft nedgravet i undergrundssandet og var omhyggeligt opbygget af kampesten af varierende størrelse helt ud til grøftens kanter.

Indvendigt i korsarmen blev der registreret et lerlag, som af udgraveren blev tolket som gulvlag inde i korsarmen. Lerlaget stiger jævnt op mod kirken. Der blev ikke registreret andre gulvlag eller lag, som kunne tolkes som gulv i korsarmen. Umiddelbart synes det bemærkelsesværdigt, at der i denne del af kirken skulle være lergulv, når den øvrige del af kirken har haft teglgulv.

I alle de udgravede felter stødte man på begravelser. De tolkes alle som hørende til den romanske kirke, idet flere af dem blev skåret af fundamenterne til korsarmen. Kun to af gravene blev udgravet, men der var ikke bevaret skeletspor i nogle af dem.

\section{Sondre korsarm}

En lille del af den søndre korsarms østmur blev udgravet i forbindelse med kirkerestaureringen i 1980. Fundamenterne til den søndre korsarm svarer i dimensioner til nordre korsarms fundamenter. Da store dele af søndre korsarm i dag er dækket af kirkegård, er der ikke foretaget yderligere udgravninger af korsarmen, men fundamenterne er eftersøgt med jordspyd, og det kan konstateres, at søndre korsarm har samme udstrækning og størrelse som nordre korsarm.

Nationalmuseets undersøgelser i 1980 viste, at den kirke, som ifølge de skriftlige kilder blev opført fra 1432, ikke var den første kirke i Testrup. Inden den tid lå der en helt almindelig romansk kvaderstenskirke bestående af kor og skib på stedet. Denne kirke svarede i størrelse og udseende til egnens andre sognekirker. I forbindelse med oprettelsen af hospitalet i begyndelsen af 1400-årene sker der imidlertid en radikal ændring. Den romanske kvaderstenskirke bliver revet ned, og man bygger en ny og langt større kirke - delvis ovenpå den gamle kirkes fundamenter.

Den nye kirke er i pagt med tidsånden en langhuskirke med tårn og korsarme. Her er tale om en kirke af helt andre dimensioner end forgængeren. En kirke som størrelsesmæssigt kan stå mål med mange af de kendte valfartskirker.

\section{Hospitalet}

Hospitalet var, ligesom det var tilfældet med kirkens vestende, under udgravning alle tre år. I begyndelsen blev der udlagt små felter henover bygningen, men mod slutningen af udgravningen smeltede felterne sammen 


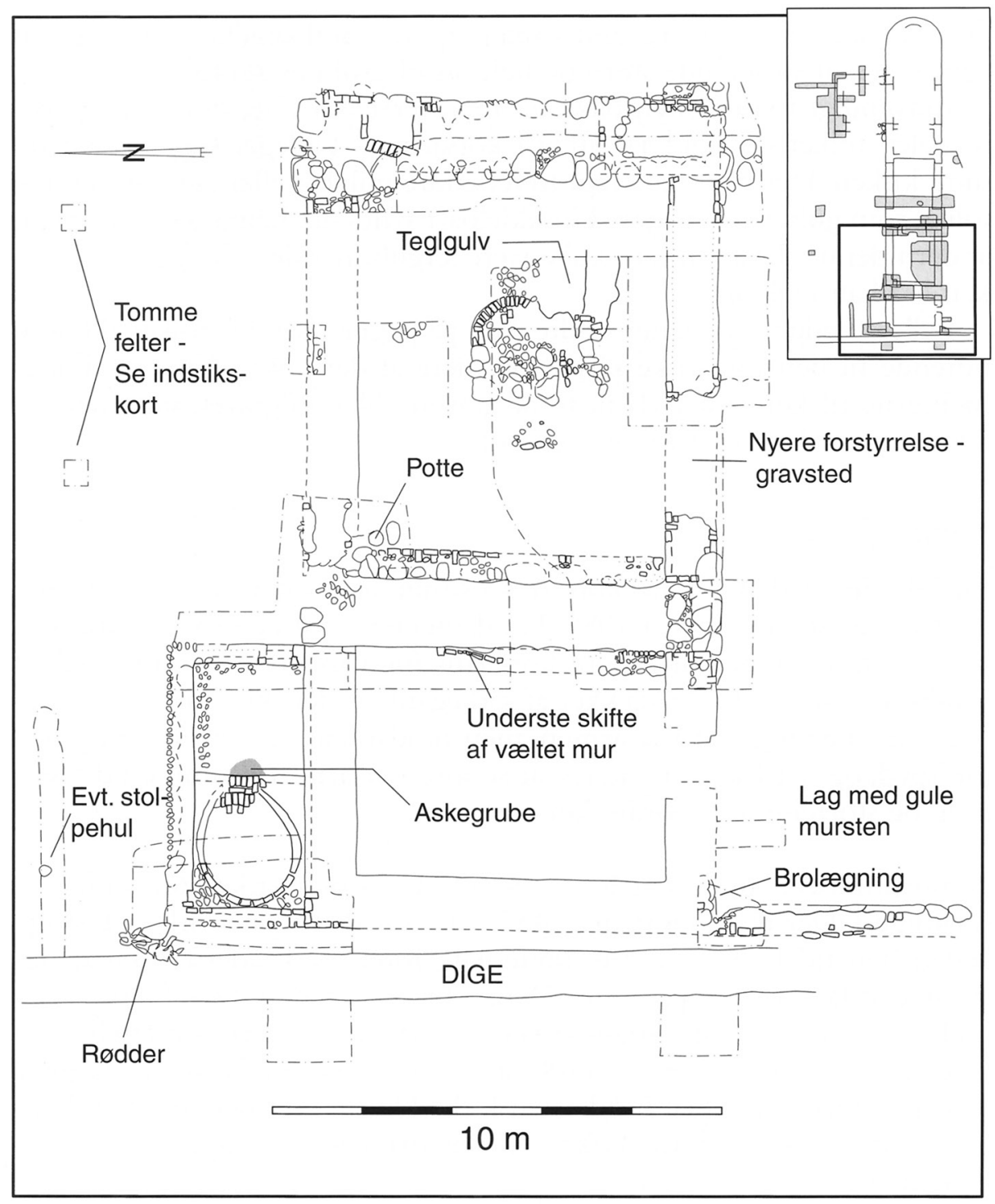

Fig. 12. Plantegning af udgravningen af hospitalet. Opmåling: Niels Junggren Have; streg: Sven Kaae.

A survey of the hospital excavation. Measured by Niels Junggren Have. Drawn by Sven Kaae.

for til sidst at ende med en totaludgravning af hospitalsbygningen samt en nord for liggende tilbygning med en bageovn (fig. 12).

Udgravningerne viste, at der vest for kirken og i umiddelbar forlængelse af denne på et tidspunkt var blevet opfort et grundmuret hus af samme 
Fig. 13. Nærbillede af den vestlige ende af hospitalets nordmur. Munkestenene er sat $i$ et regelmæssigt munkeskifte ovenpå et kampestensfundament. Foto: Niels Junggren Have.

A close-up of the western end of the northern hospital wall, which is built in the so-called "monk's course" (a staggered course of two stretchers and one header) on top of a boulder foundation. Photo: Niels Junggren Have.

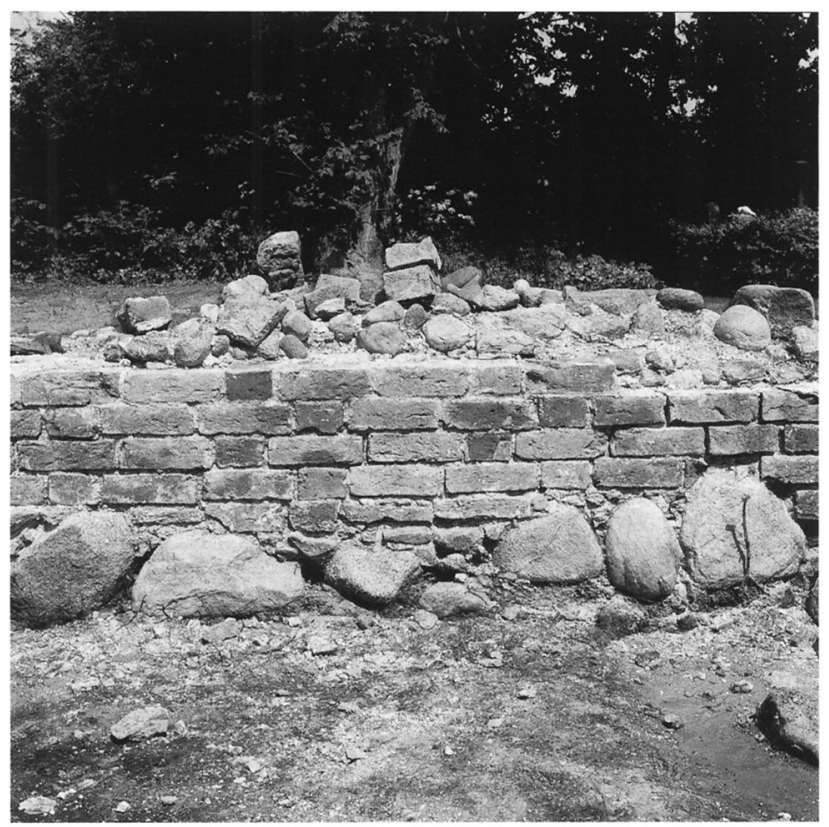

Fig. 14. Dele af hospitalets sydmur, hvor muren støder op til kirken. Det er tydeligt, at der ikke er forbandt mellem murene $i$ de to bygninger. Hospitalsmuren er endvidere et illustrativt eksempel på en kassemur. Foto: Niels Junggren Have.

The part of the south wall of the hospital, which is adjoining the church. The lack of a bond between the two buildings is obvious. The photo also illustrates the construction of the hospital wall. Photo: Niels Junggren Have.

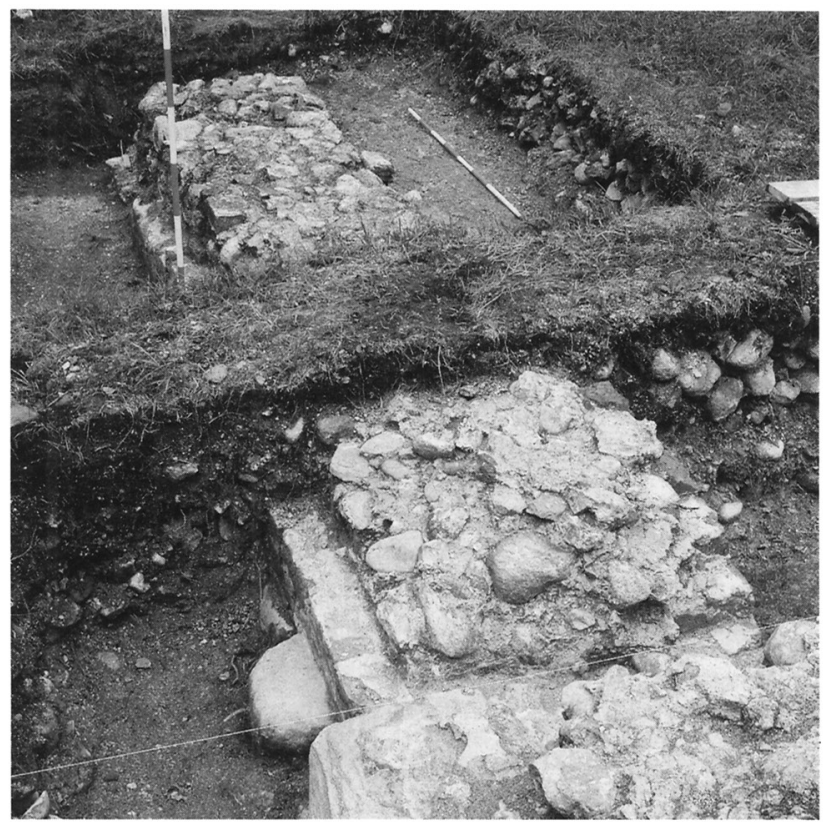

bredde som kirken $(9 \mathrm{~m})$ og med en længde på ca. 16,5 m. Det fremgik tydeligt, at bygningshistorien kunne deles $i$ mindst to faser. I den ældste fase bestod bygningen af ét stort rum, mens den i sin anden og endelige udformning var opdelt i et $9 \times 9 \mathrm{~m}$ stort rum (udv. mål) mod øst, derefter 
en portgennemgang på ca. 11/2 m’s bredde (indv. mål) og endelig længst mod vest et ca. $6 \times 9 \mathrm{~m}$ stort rum (udv. mål). Desuden var der nord for det vestre rum og op til dettes ydermure opført en bygning, ca. $6 \times 3 \mathrm{~m}$ (udv. mål).

Bygningens ydermure var opført på et kampestensfundament, der fulgte det mod vest faldende terræn; efter alt at dømme oprindelig med soklen ragende op over terræn. Ydermurene var relativt velbevarede, især mod vest, hvor der var bevaret op til seks skifter (fig. 13). Omkring bygningens midte var sydmuren brudt totalt ned, og det samme giorde sig gældende ved bygningens nordvest-hjørne. Begge steder var fundamentet også fjernet.

Selve muren var en $115 \mathrm{~cm}$ bred kassemur svarende præcis til kirkemurene (fig. 14). Munkestenene var sat i et regelmæssigt munkeskifte. Murene var bygget helt op til kirkens vestgavl - dog uden at være i forbandt med denne. Murene har stået pudset både udvendigt og indvendigt, ganske som kirken.

Der er meget få detaljer at spore i murværket. I sydmuren til det vestre rum findes resterne af en ca. $85 \mathrm{~cm}$ bred døråbning muligvis med fals både udvendig og indvendig. Som omtalt ovenfor har der ligeledes været adgang til bygningen via kirkens vestgavl. Om der har været andre indgange til bygningen er usikkert, men der kan have været en indgang i den helt nedbrudte del af sydmuren. Desværre er der ikke bevaret så meget af murværket, at det har været muligt at iagttage spor efter vinduesåbninger, gemmenicher el.lign.

Der har været yderligere to åbninger i murene, nemlig i form af en portgennemgang ca. $9 \mathrm{~m}$ fra kirkens vestgavl (fig. 15). Porten er tydeligvis ikke en del af bygningens oprindelige planløsning. Både hvad angår konstruktion og materialevalg adskiller portmurene sig tydeligt fra bygningens øvrige ydermure, ligesom der heller ikke er forbandt mellem de to typer mure. I stedet er der forbandt mellem portens vestmur og bageovnsbygningens østmur, således at porten og bageovnsbygningen må være samtidige (fig. 16).

Portmurene er opbygget som en ca. 50-60 cm bred kassemur; bygget på en sokkel af kampesten i 50-80 cm's højde. På grundlag af nedbrydningsmaterialet ser det ud til, at store dele af muren ud mod porten har bestået af kampesten, mens der ind mod rummene har været munkesten. Munkestenene her adskiller sig både størrelses- og farvemæssigt fra munkestenene i bygningens øvrige mure, ${ }^{21}$ og skiftegangen er krydsskifte i stedet for munkeskifte. Kampestensmurene har været pudset med sandet ler, der endnu kunne ses yderst i fugerne mellem stenene, særligt i portens sydøstre hjørne.

Mod nord var portåbningen brolagt, mens der inde i selve porten, i samme niveau som brolægningen, var grusblandet jord. I den sydlige 
Fig. 15. Kig fra sydøst henover portåbningen i hospitalsbygningen. Det er tydeligt, at portmurene ikke er en del af bygningens oprindelige planløsning, idet både konstruktion og materialevalg adskiller sig fra bygningens øvrige ydermure. Foto: Niels Junggren Have.

A view from the $\mathrm{SE}$ towards the passage through the hospital. The photo illustrates the fact that the passage walls were not part of the original layout, as both the construction and the material used for the passage differ from the outer walls of the building. Photo: Niels Junggren Have.

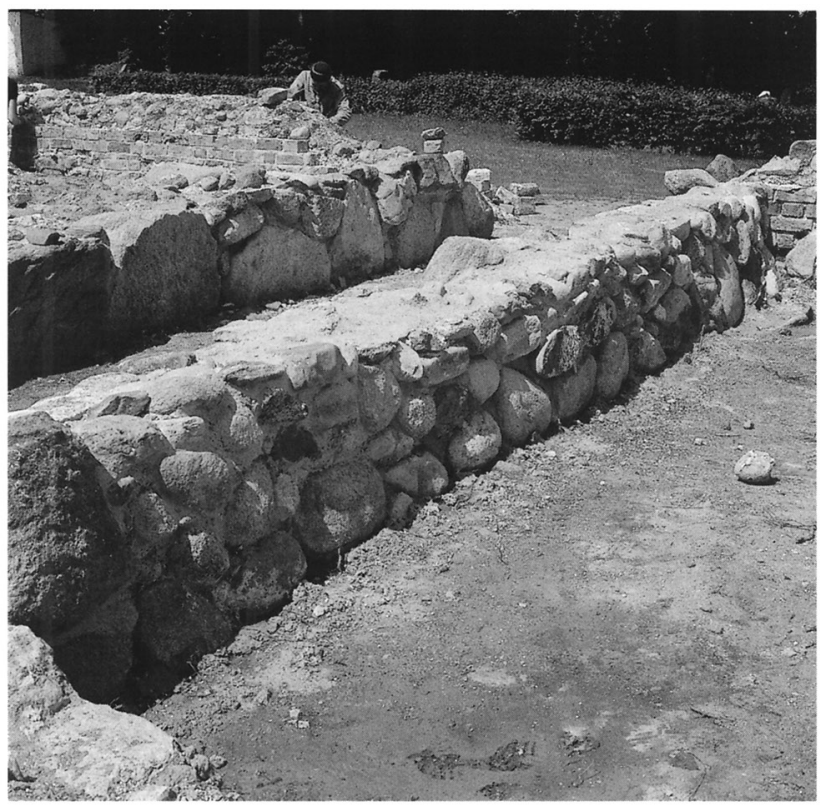

Fig. 16. Detalje af murværket mellem portåbningen og bageovnsbygningen ved portåbningens nordvesthjørne. Der er tydeligvis forbandt i murværket, som er opmuret i krydsskifte. Foto: Niels Junggren Have.

A detail of the brickwork between the passage and the building with the baking oven at the NW-corner of the passage. The wall is constructed from alternating courses of runners and headers. Photo: Niels Junggren Have.

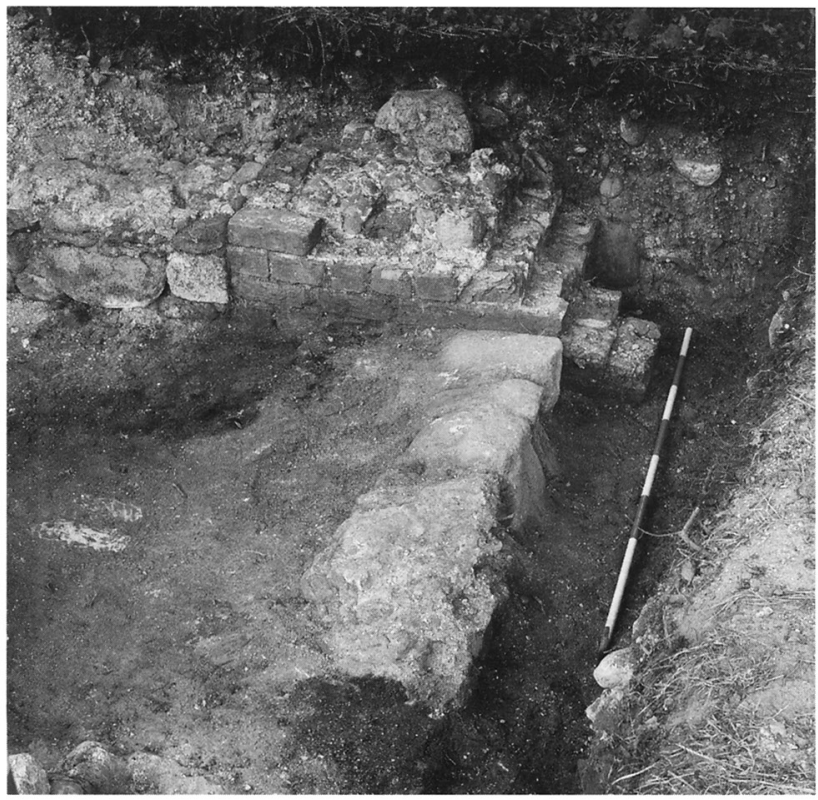

portåbning var bunden dækket af sandet gråt ler - der kan muligvis være tale om resterne af en form for belægning over gruset svarende til de pudsede portmure. Under portbelægningerne i flugt med bygningens ydermure blev resterne af det nedbrudte fundament registreret. 


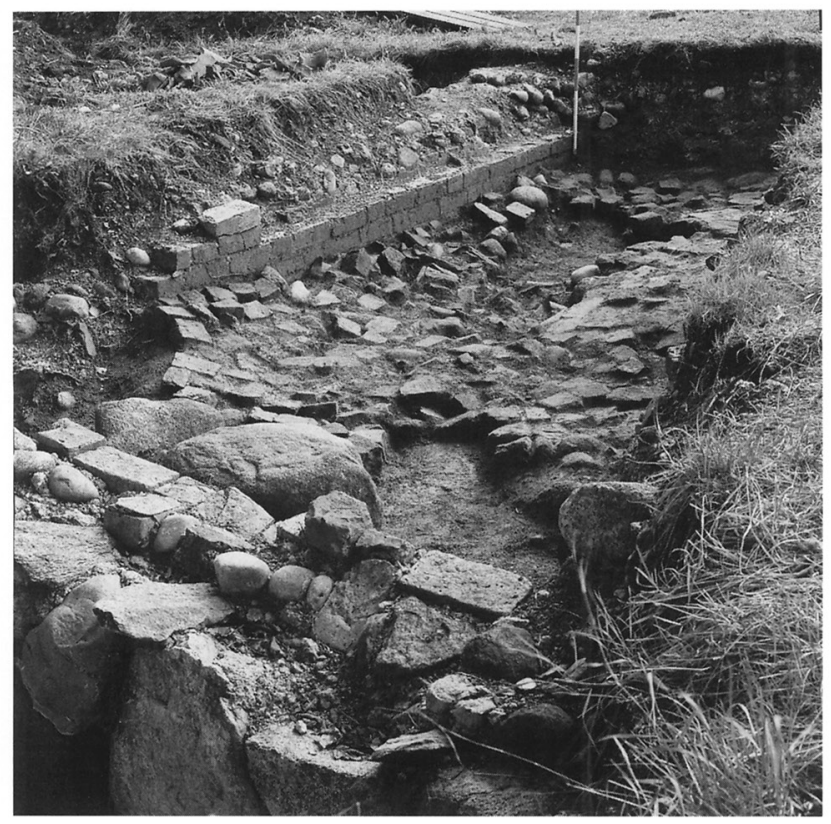

Fig. 17. Den nordlige del i hospitalets store rum. Det yngste gulv i denne del af bygningen var et meget ujævnt gulv lagt af hele og halve munkesten. Foto: Niels Junggren Have.

The northern part of the large room of the hospital. The last floor in this part of the building was very uneven and made from bricks and halfbricks. Photo: Niels Junggren Have.

Indvendigt i bygningen er der flere steder bevaret rester af munkestensgulve. Der kan med sikkerhed udskilles to gulve, men om der er tale om flere, er det p.g.a. dokumentationsniveauet ikke muligt at afgøre. Det ældste munkestensgulv er sandsynligvis registreret i savel det vestlige som det østlige rum, og i det sidstnævnte fortsætter gulvet tilsyneladende ind under portmurenes fundament. Det må formodes, at der er tale om det ældste gulv i bygningen, da den endnu var udelt.

Højere oppe og umiddelbart under nedbrydningslaget blev der iagttaget et meget ujævnt munkestensgulv bestående af hele og halve munkesten lagt i gult sand (fig. 17). Dette gulv må stamme fra tiden efter portgennembrydningen og er kun registreret i bygningens store rum mod øst.

Midt i hospitalets store rum var der bevaret resterne af et større, tilsyneladende fritstående ildsted/kamin, 1,9 m bredt og 2,4 m dybt. Kaminen har mod vest en lige kant sat af kampesten, mens der mod øst er en runding sat af kantstillede munkesten. Det er temmelig usædvanligt med en fritstående kamin, og det er spørgsmålet, om der ikke har været en let skillevæg i rummet, som blot ikke blev erkendt under udgravningen. Herved bliver den østlige del af rummet til stue med en kamin eller bilæggerovn, som kunne fyres fra ildstedet i køkkenet mod vest.

I det nordvestre hjørne af rummet, ca. 30-40 cm fra hospitalets nordmur og helt op til den østre portmur, blev der fundet en næsten komplet jydepotte med udadbøjet rand og glittet overflade (fig. 18). Potten var gravet ned gennem det øvre teglgulv. Umiddelbart syd for potten lå en 
Fig. 18. Foto af den jydepotte, som antages at have fungeret som glødepotte. Dele af randen mangler. Foto: Preben Dehlholm.

A pot with a broken rim thought to have been used for live coal. Photo: Niels Junggren Have.

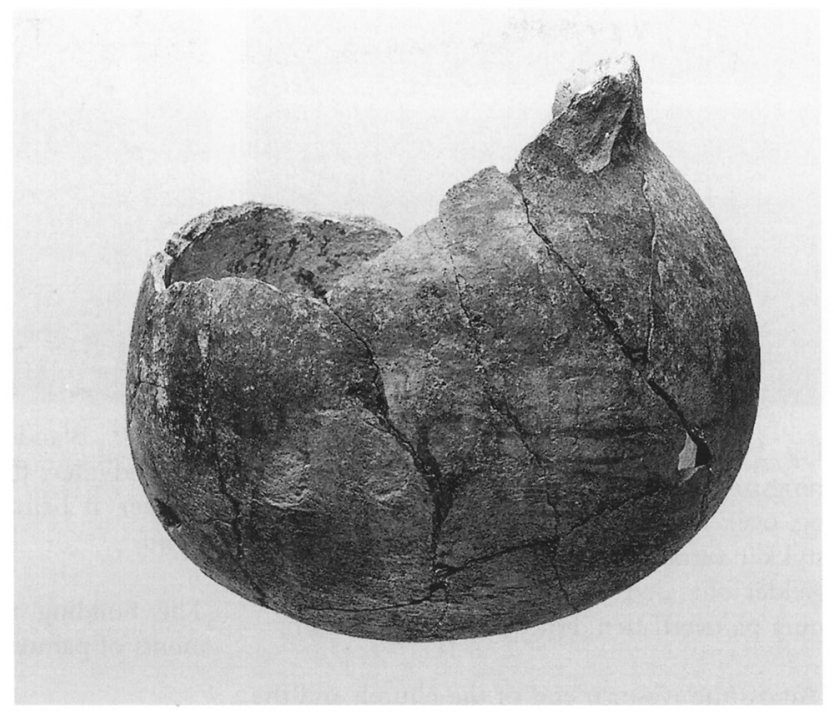

større sten, som ragede mellem 10-15 cm op over gulvniveau. Om stenen har en funktion i tilknytning til potten er uvist. Der var en del trækulsstykker i og omkring potten, og den tolkes derfor som en glødepotte.

I de massive mængder af nedbrydningsmateriale, som lå henover hele bygningen, blev der fundet utrolig meget tagtegl, således at man må formode, at taget har været beklædt med munke-nonner (fig. 19).Visse steder fandtes ligeledes store sammenhængende murpartier, som enkelte gange fremtrådte pudsede og bemalede med sparrer i rødt og sort (fig. 20). De bemalede sten tolkes som hvælvsten, idet der også blev fundet ribbesten med denne form for bemaling. Der kan altså ikke være megen tvivl om, at bygningen har været overhvælvet.

\section{Bageovnsbygningen}

Nord for hospitalet og bygget op ad dennes nordmur fandtes resterne af en ca. $6 \times 3 \mathrm{~m}$ stor bygning (udv. mål). Bygningens vestmur flugter med hospitalets vestmur, uden at de er muret i forbandt. Østmuren i bygningen flugter med portens vestside, og som næunt ovenfor er de $i$ forbandt med hinanden og derfor samtidige. I bygningens vestlige ende var der bevaret resterne af en bageovn, og bygningen benævnes derfor bageovnsbygningen (fig. 21).

Bygningens ydermure er opført af munkesten som kassemure med en 


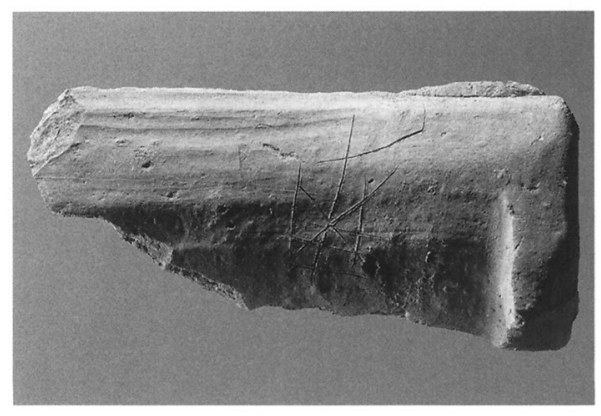

Fig. 19. Der lå massive mængder af nedbrydningsmateriale henover hele kirkens vestende og over hospitalsbygningen. Enkelte af disse stykker tiltrak sig ekstra opmærksomhed. Det gælder bl.a. dette stykke tagtegl med indridsning på overfladen. Foto: Preben Dehlholm.

Across the western end of the church and the hospital building lay large amounts of building rubbish from the demolition. Some were of a special interest, as for instance this fragment of a tile with a sketch on the surface. Photo: Preben Delholm.

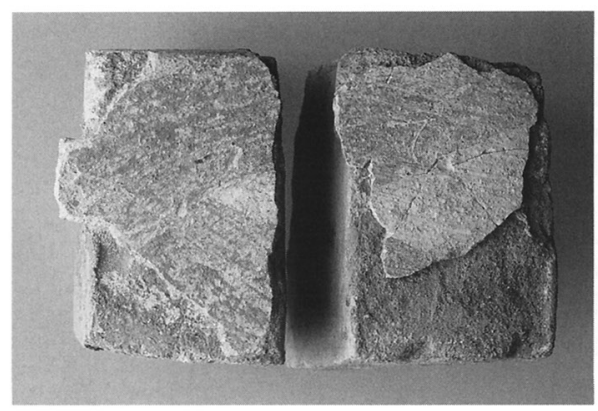

Fig. 20. Blandt nedbrydningsmaterialet blev der endvidere fundet flere hvælvsten med fragmenter af bemalet puds. Foto: Preben Dehlholm.

The building rubbish included several fragments of painted stones from the vault.

bredde på mellem 40 og $50 \mathrm{~cm}$, hvilket modsvarer dimensionerne af portmurene. Nordmuren har muligvis været en anelse bredere, men da der ikke er bevaret murværk her, kan det være fundamentsbredden, der snyder. Det nordlige fundament er plyndret for de store sten, men aftrykkene efter stenene stod tydeligt. Fundamentet var her mod nord pænt kantet af en enkelt række pigsten lagt helt op til fundamentsstenene.

I østmuren, tæt op til hospitalsbygningen, ses resterne af en smal dør $(55 \mathrm{~cm})$ med dørtrin af tegl hævet et skifte over porten. Døren har fals på den indvendige side.

Den vestlige halvdel af bygningen rummede en omtrent cirkulær bageovn opbygget af munkesten og rækkende omtrent fra mur til mur. Ovnen var bevaret med op til tre skifter sten, hvilket var nok til at give en fornemmelse af ovnens hvælving. Bageovnens indvendige diameter var øst-vest ca. $2,5 \mathrm{~m}$ og nord-syd $2 \mathrm{~m}$ (fig. 22). Over bageovnen lå et kompakt lag leret sand med teglbrokker; muligvis er der tale om resterne af den sammenstyrtede ovn. Udenfor ovnen i hjørnerne lå et isolerende lag af gult sand og store kampesten. Der kunne iagttages askelag foran ovnåbningen.

Brolægningen i den nordre portåbning fortsætter hen forbi bageovnsbygningen. 
Fig. 21. Bageovnsbygningen set fra øst. Bageovnen, som har givet navn til bygningen, fylder hele den vestlige halvdel af bygningen. Foto: Niels Junggren Have.

The building with the baking oven seen from the East. The oven takes up the whole western part of the building. Photo: Niels Junggren Have.

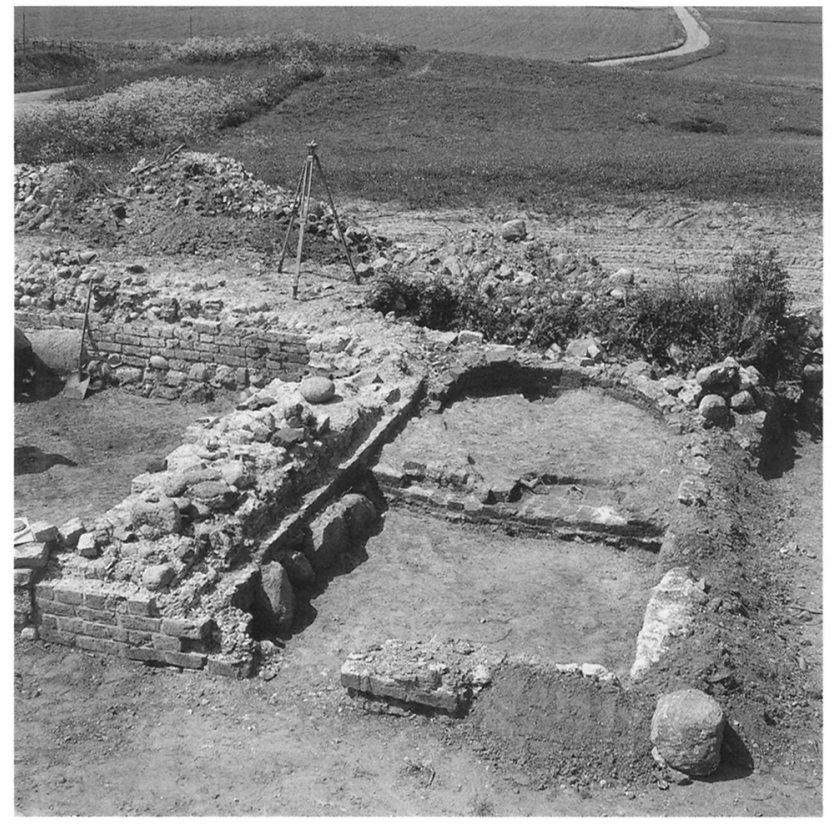

Fig. 22. Detalje af bageovnens vestende. Der er bevaret tilstrækkeligt af ovnen til at give en fornemmelse af ovnens hvælving. I hjørnet nederst i billedet ses et isolerende lag af gult sand og store kampesten. Foto: Niels Junggren Have.

A detail of the western end of the baking oven. Enough of the oven is preserved to give an impression of the convexity of the structure. An insulating layer of yellow sand and large boulders can be seen in the corner at the bottom of the photo. Photo: Niels Junggren Have.

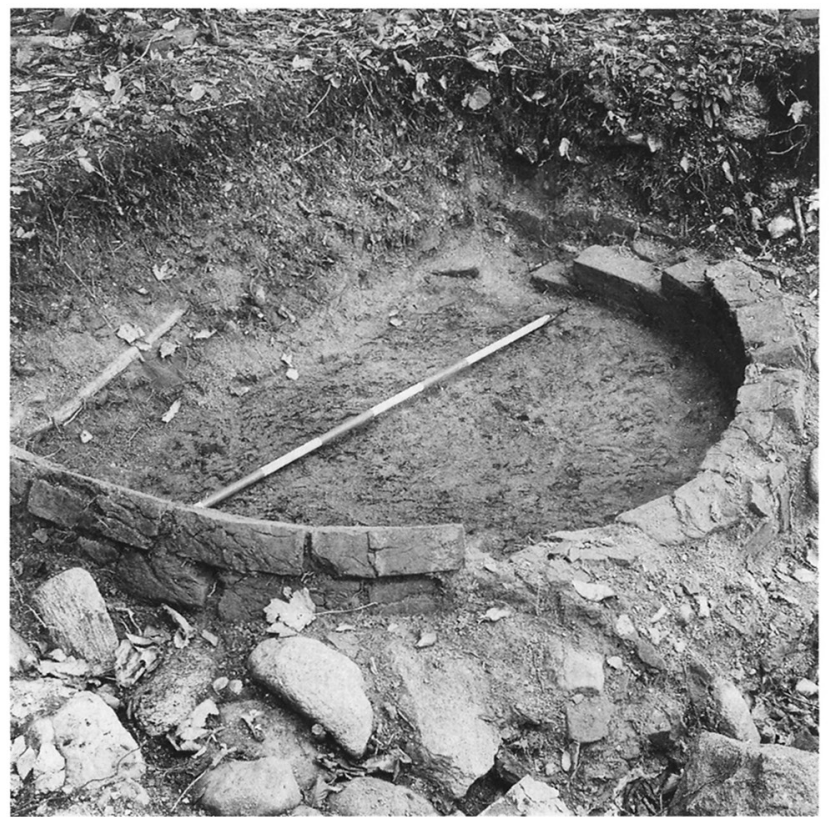

Hospitalet, portåbningen og bageovnsbygningen repræesenterer flere faser af hospitalets historie.

I sin ældste udformning var hospitalet én stor bygning uden port, hvilket fundamentsresterne i portåbningen viser. Der var indgang til byg- 
ningen via kirkens vestgavl, og døren mod vest i hospitalets sydmur er antagelig også oprindelig. Der kan ligeledes også have været en indgang $\mathrm{i}$ det helt nedbrudte murforløb omkring bygningens midte, men det kan ikke dokumenteres med sikkerhed. Bygningen kan have været $i$ to etager, hvor i hvert fald den nederste etage har været hvælvet.

På et tidspunkt ændres hele bygningens planløsning. Der bliver etableret en portgennemgang i bygningen, hvorved den deles i mindst to rum, og bageovnsbygningen bliver bygget til. Disse ændringer må være del af en samlet og samtidig plan, idet der er forbandt mellem portmurene og bageovnsbygningen. Det er svært at datere denne ændring i byggeriet. Murværket i portåbningerne er muret i krydsskifte, men det afgør ikke med sikkerhed, om ændringen er kommet til før eller efter reformationen, men da portåbningerne ligeledes er muret uden fals, hvilket er usædvanligt i middelalderen, anses ændringen for at være efterreformatorisk.

Efter etableringen af portåbningen og en opdeling af bygningen $i$ mindre rum, fremstår bygningen som en tidssvarende bolig. I laget under gulvet blev der fundet en enkelt hulpenning fra 1450-1500, måske endda senere. ${ }^{22}$ Alt peger således på, at der er tale om en efterreformatorisk ændring, som sandsynligvis skal ses i forbindelse med nedlæggelsen af hospitalet i $1545 .{ }^{23} \mathrm{Vi}$ ved ikke, hvorfor eller hvem der har stået for ombygningen af hospitalet til bolig, men et bud kunne være, at hospitalet efter nedlæggelsen bliver ombygget til præstebolig. ${ }^{24}$

Der blev ikke gravet til undergrund i nogle af de felter, som dækkede hospitalet og bageovnsbygningen. Det er derfor vanskeligt at udskille forskellige faser i byggeriet samt ikke mindst afgøre, om der evt. er faser xldre end det store stenbyggeri.

\section{Bygningslevn på kirkegården}

Under udgravningen af selve hospitalsbygningen blev der ved bygningens sydvest-hjørne registreret et ca. $70 \mathrm{~cm}$ bredt nordsydgående fundament. I et forsøg på at registrere mere af denne bygning samt for at lokalisere eventuelle andre bygninger hørende til hospitalet blev der anlagt en række felter rundt om på kirkegården. Felterne blev anlagt i de gravsteder og på de stier, hvor det var muligt at komme til. Det er siden lykkedes at identificere og placere 24 felter, men det fremgår klart af materialet, at der har været flere felter rundt omkring. De felter, som ikke er nøjere beskrevet i dokumentationsmaterialet, antages at have givet et negativt resultat.

Det nordsyd-gående fundament, som udgik fra hospitalets sydvesthjørne, blev fulgt over en strækning på $5,7 \mathrm{~m}$, uden at murens sydlige afslutning blev påvist (fig. 23). Tilsyneladende var muren opbygget som en smal kassemur i stil med bageovnsbygningens ydermure. Dokumen- 
Fig. 23. Kig mod nord op mod hospitalets vestende. Til venstre ses resterne af det nord-sydgående fundament, som udgik fra hospitalets sydvest-hjørne. Foto: Niels Junggren Have.

A view of the western end of the hospital seen from the South. To the left are the remains of the NS-running foundation starting off from the SW-corner of the hospital. Photo: Niels Junggren Have.

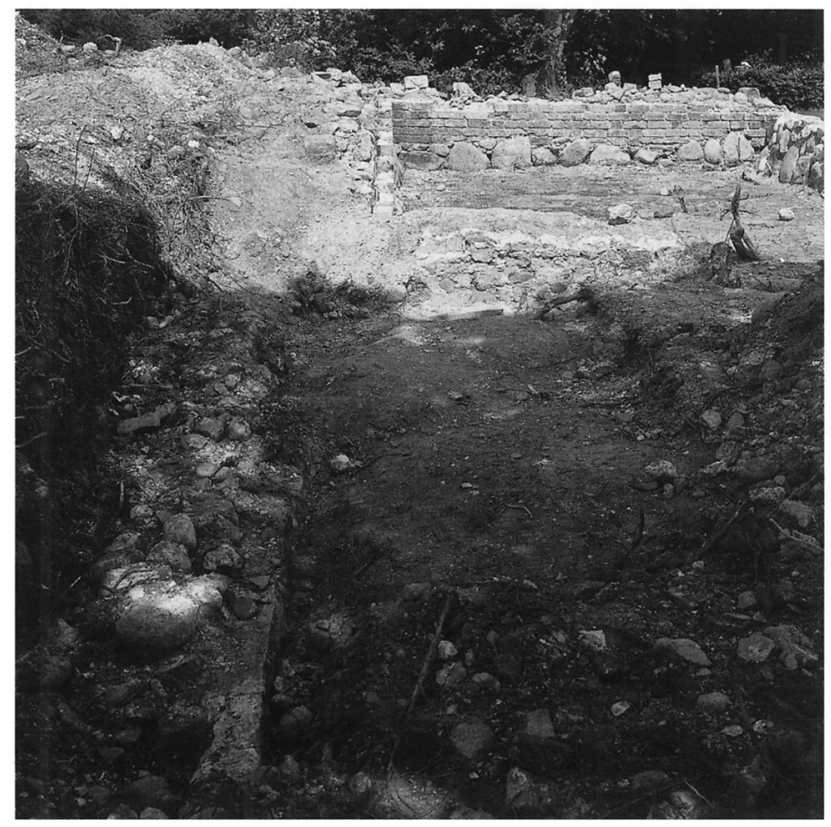

tationsmaterialet er dog ikke helt entydigt, så det kan ikke afgøres med sikkerhed, om det forholdt sig således. Op mod sydvesthjørnet af hospitalsbygningen blev der påvist resterne af en brolægning, mens der i et mindre felt mod øst blev påvist rester af en munkestensbelægning. Belægningerne lå i samme niveau, og der kan således være tale om et gulvlag inde $i$ en bygning. Til trods for at der ikke blev påvist et fundament mod øst, tolkes det fundne murforløb samt gulvbelægningerne som hørende til en lettere, sydgående bygningsfløj.

Der blev anlagt yderligere to felter i den sydlige forlængelse, men felterne kan ikke placeres med sikkerhed, og det vides derfor ikke, om de var placeret i eller uden for fundamentsforløbet. Begge felter var fundtomme.

Ud fra den rimelige formodning, at der kunne være tale om et firfløjet anlæg, blev der ligeledes udlagt en række felter syd for hospitalets østende - altså ved overgangen mellem kirke- og hospitalsbygning. Her lykkedes det at følge et nord-sydgående fundament over en strækning på ca. $12 \mathrm{~m}$.

Der var tale om et kraftigt fundament opbygget af kampesten uden spor af mørtel. Det var ikke muligt i nogle af felterne at erkende fundamentets nøjagtige bredde, som har været minimum $1,85 \mathrm{~cm}$. Ca. $18 \mathrm{~m}$ syd for kirken blev fundamentshjørnet fundet, og herfra fortsatte fundamentet mod øst. 


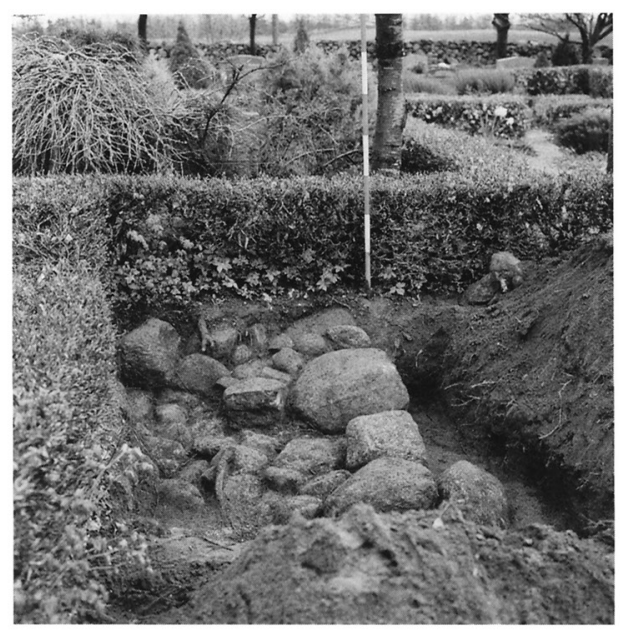

Fig. 24. Det var trangt at grave i de felter, som blev anlagt rundt om på kirkegården. På billedet ses resterne af det store øst-vest gående fundament, som var opbygget af kampesten uden spor af mortel. Foto: Niels Junggren Have.

The archaeologists had a hard time digging in the churchyard, as the areas being excavated were very small. This photo shows the remains of the large foundation running E-W. It was build from boulders and had no traces of mortar. Photo: Niels Junggren Have.

Det kan ikke afgøres, om fundamentet gik helt op til tårngavlen. Tilsyneladende blev der op mod kirken og hospitalet fundet resterne af en brolægning, og det er derfor sandsynligt, at der har været en åbning i muren/diget her.

Det kraftige kampestensfundament blev fulgt mod øst ved anlæggelsen af en lang række felter. Fundamenterne i de forskellige felter formodes at repræsentere det samme fundamentsforløb. Enkelte steder var det muligt at udgrave hele fundamentsbredden, og her kunne den måles til ca. $2 \mathrm{~m}$. Opbygningen af fundamentet var som ved det nord-sydgående større og mindre kampesten uden mindste spor af mørtel (fig. 24). I ingen af felterne var det muligt at måle fundamentsdybden. Ifølge tegningsmaterialet stopper fundamentet meget brat omtrent i flugt med kirkens østlige afslutning - uden fortsættelse mod hverken syd eller nord. Denne bratte afslutning fremgår imidlertid ikke tydeligt af fotomaterialet.

Det er vanskeligt at afgøre, hvad fundamenterne egentligt repræsenterer. Der er tale om meget kraftige fundamenter, som umiddelbart leder tanken hen på et større byggeri, men da der ikke er registreret andre, parallelle fundamentsforløb, må der være tale om et meget kraftigt funderet dige/mur.

Også nord for hospitalsbygningen blev der eftersøgt eventuelle bygningsspor. I flere af felterne blev der iagttaget svage spor af bebyggelse i form af en mulig syldstensrække samt nogle gule lerlag, som muligvis kan tolkes som gulvlag. Dokumentationen af felterne er imidlertid for dårlig til, at der kan foretages en sikker tolkning af disse iagttagelser, men det ville være interessant at undersøge det nærmere for at se, om der kunne være 
tale om bygningsspor ældre end hospitalsbygningen. Det øverste gule lerlag nærmest hospitalet synes i hvert fald at blive skåret af fundamentsgrøften til hospitalsmuren.

Vest for det nuværende kirkegårdsdige blev der også anlagt en række felter. Samtlige felter var fundtomme, og det kan dermed fastslås, at byggeriet koncentrerer sig til toppen af bakken.

Samtidig er det væsentligt at bemærke, at der kun blev påtruffet grave øst for hospitalsbygningen, hvilket støtter tolkningen af det kraftige stenfundament som rester af et kirkegårdsdige/-mur.

\section{Begravelser}

Under udgravningen af kirkens vestende blev der i tårnrummet udgravet 13 begravelser. Det lykkedes ikke i alle tilfælde at udskille de enkelte grave fra hinanden, og flere af begravelserne blev udgravet som et samlet kompleks af grave (fig. 25). Efter udgravning blev skeletterne sendt til bestemmelse på Københavns Universitets Antropologiske Laboratorium, hvor de blev undersøgt af Balslev Jørgensen. ${ }^{25}$

Af de 13 begravelser var de syv børn på 10 år og derunder, to var henholdsvis 18 og 20 år gamle, mens de resterende fire var 30 år og derover. På tre af skeletterne var det muligt at iagttage sygelige forandringer. Det drejer sig dels om et 10 års barn med meget svære sygelige forandringer $i$ halshvirvelsøjlen (fig. 26). Der var total destruktion af to hvirvellegemer og delvist sammenfald af to tilstødende hvirvler, hvilket har bevirket sammenfald af halsen med pukkeldannelse til følge (fig. 27). Årsagen kan ikke angives med sikkerhed, men efter al sandsynlighed drejer det sig om tuberkulose. Der blev ikke fundet tegn på tuberkulose i andre knogler.

I en anden grav blev der fundet det meste af et helt skelet; de fleste af halshvirvlerne manglede dog, uden at man kunne finde nogen rimelig forklaring herpå. Der er formodentligt tale om en kvinde på ca. 18 år. Der er meget svære sygelige forandringer på skeletdelene, dels i venstre lårben, dels i højre skinneben, hvor der har været svære betændelsesforandringer med tydelig forkortning af benene til følge. Da det drejer sig om forkortning af begge ben, kan der ikke påvises nogen større skævhed i bækkenet, men at patienten har været svært forkrøblet, kan der ikke være nogen tvivl om. Dødsårsagen har utvivlsomt været følgerne efter de svære betændelsestilstande. Disse betændelsestilstande kan ligeledes have været forårsaget af tuberkulose. ${ }^{26}$

Det sidste skelet, hvor der er iagttaget sygelige forandringer, er sandsynligvis en mand på mellem 30 og 40 år. Det drejer sig om forkalkninger i ledbånd og muskelfæster, som tegn på hård legemlig belastning livet igennem. Der er endvidere ganske let slidgigt såvel i skuldre som i knæ- 

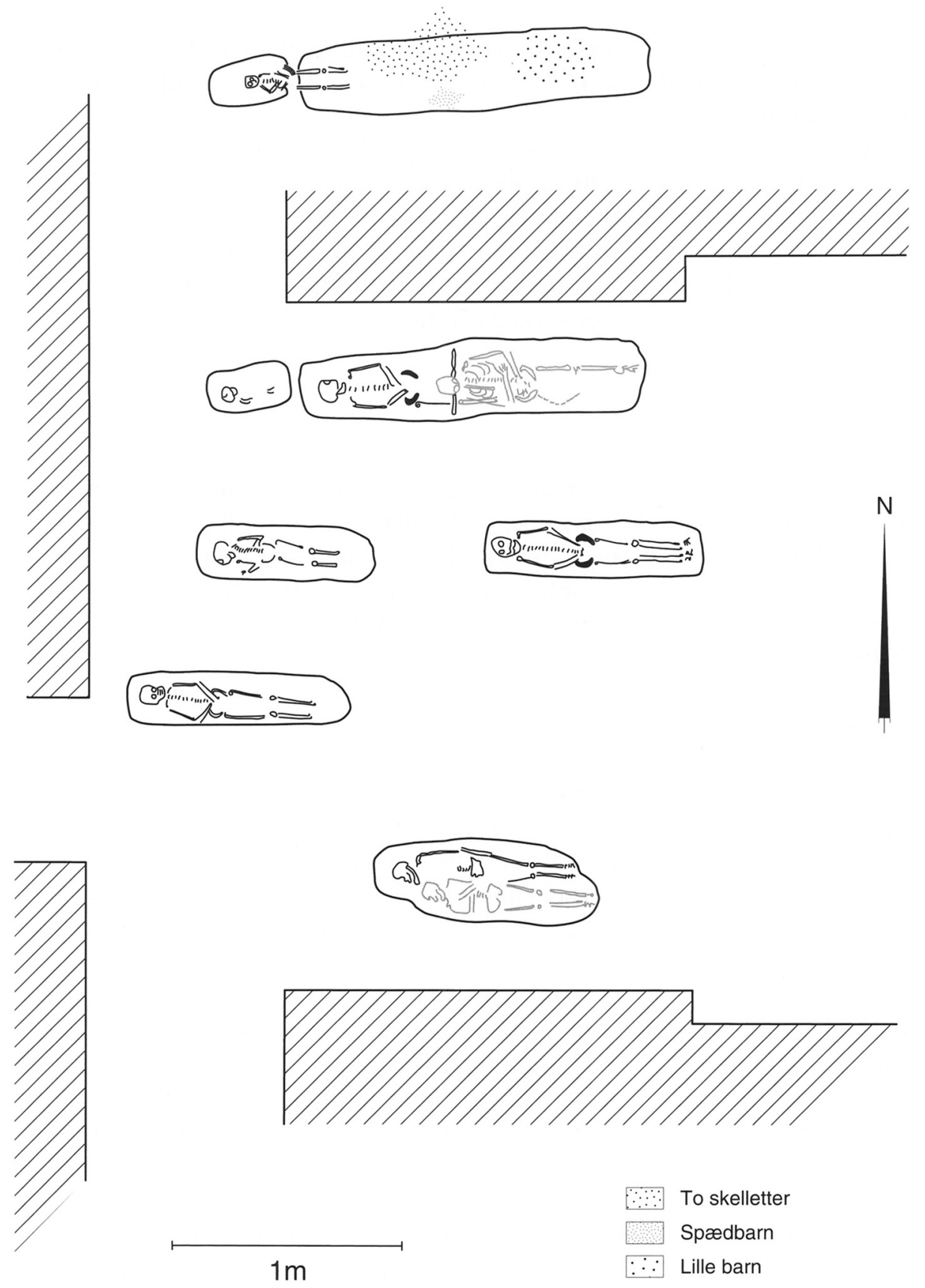

Fig. 25. Plan af gravene i kirkens tårnrum. Mod nord var der et stort antal begravelser oven $i$ hinanden, og det var ikke muligt at udskille de enkelte grave fra hinanden her. Opmåling: Niels Junggren Have; streg: Sven Kaae.

A survey of the graves in the church tower. The northern part of the tower contained a large amount of burials, which could not be segregated. Measured by Niels Junggren Have. Drawn by Sven Kaae. 


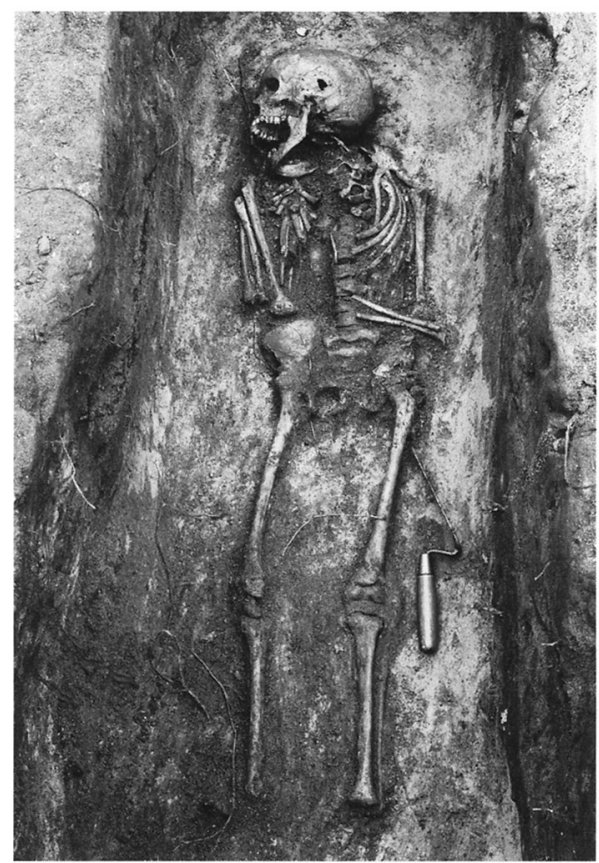

Fig. 26. Skelettet af et 10-årigt barn. Rygsøjlen er deformeret på grund af tuberkulose. Se også fig. 27. Foto: Niels Junggren Have.

The skeleton of a 10-year-old child. The spine is deformed due to tuberculosis. See also fig. 27. Photo: Niels Junggren Have.

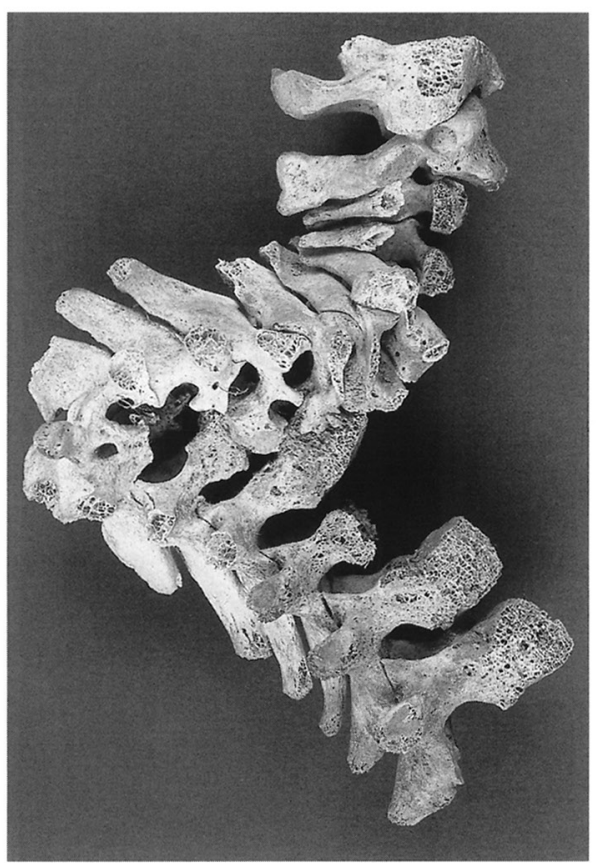

Fig. 27. Nærbillede af den 10-åriges rygsøjle, som er deformeret med en krumning på 180 grader, hvilket har medført pukkeldannelse. (Efter Bennike 1999, s. 516.)

A close-up of the spine in fig. 26. The disease caused the development of a hunchback. (From Bennike 1999, p. 516.)

og ankelled. I modsætning til de to øvrige skeletter er der her tale om almindelige aldersbestemte forandringer.

Da der, som det er naturligt ved kristne begravelser, ikke er fundet genstande $\mathrm{i}$ gravene, kan der ikke gives nogen absolut datering på begravelserne. Da der samtidig ikke er nogen detaljerede tegninger af gravene og deres forhold til de omgivende lag, er det svært at datere gravene i forhold til kirkebyggeriet. På grund af deres placering i tårnrummet, hvor de klart respekterer murforløbene, synes det dog rimeligt at antage, at de er samtidige med kirken og dermed også samtidige med hospitalet.

De skeletter, hvor der kunne iagttages svære sygelige forandringer, synes da også at pege på og understrege stedets funktion som hospital. Antallet af skeletfund, hvor tuberkulose har sat spor i knoglerne, er forsvindende lille i Danmark, kun $0,1 \%$ af de udgravede skeletter. ${ }^{27}$ I Testrup har to ud af 13 skeletter knoglemæssige forandringer, som kan skyl- 


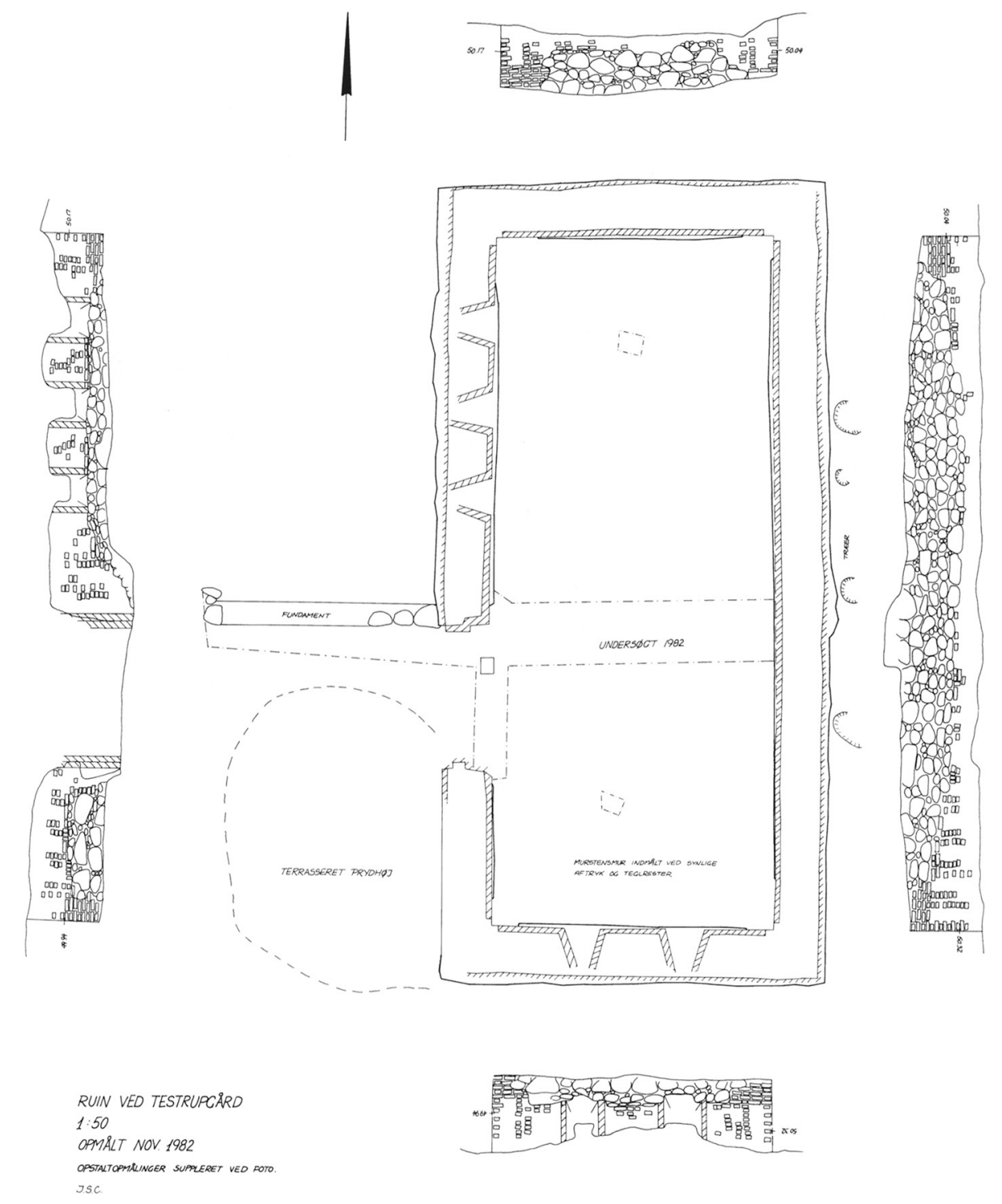

Fig. 28. Plantegning samt opstalt af vestmuren i Testrup stenhus. Opmåling og streg: Jan Sloth Carlsen.

A survey and elevation of the west wall in Testrup Stenhus. Measured and drawn by Jan Sloth Carlsen.

des tuberkulose. Statistisk set er 13 skeletter et ringe antal, men det er dog påfaldende, at der på to ud af 13 skeletter findes så svære sygelige forandringer et sted, hvor vi kender til hospitalsfunktionen. 
Fig. 29. Vinkelret på vestmuren i Testrup stenhus, i flugt med døråbningens nordside, blev der iagttaget resterne af et smalt fundament. Foto: Niels Junggren Have.

At right angles to the west wall of Testrup Stenhus and level with the north side of the doorway were the remains of a small foundation. Photo: Niels Junggren Have.

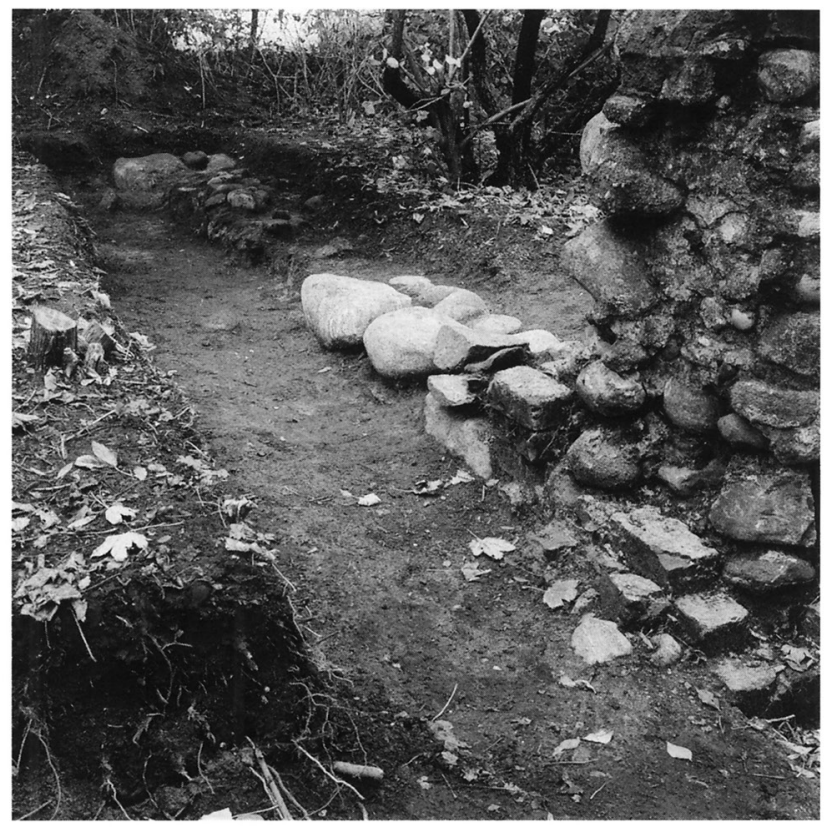

\section{Ruinen i Testrupgårds have}

I haven øst for det nuværende Testrupgård og ca. 100 m SSV for kirken ligger ruinen af et 18,8×9 m (udv. mål) stort stenhus. Kristen Sørensen Testrup, som blev født på Testrupgård i 1685, skrev i 1732 i sin "Rinds herreds Krønike", at på Testrupgård var et "ypperligt grundmuret Hus, 3 Loft höjt, hvilket blev brugt til Ralingshus for den ene Mand, som havde den halve Testrupgård indtil 1670, da Jakob Jensen, som bebode den anden halve Part af Gården, fæstede den tilhobe og da nedbrød og ødelagde bemeldte grundmurede Hus; dog var Murene så stærke, at en Del deraf står endnu på denne dag 1732." ${ }^{28}$ Der kan ikke være nogen tvivl $\mathrm{om}$, at det grundmurede hus er identisk med ruinen i Testrupgårds have. Ruinen blev fremgravet omkr. 1860, og i $1943 \mathrm{blev}$ den fredet. ${ }^{29}$

I forbindelse med udgravningerne af kirken og hospitalet blev der i 1982 lavet en plantegning af ruinen samt opstalter af bygningens indvendige mure (fig. 28). Man lavede ligeledes nogle få prøvehuller og en enkelt søgegrøft i og ved ruinen.

Opmålingen viste, at der var tale om et stort stenhus, hvis mure var 
bevaret $\mathrm{i}$ en højde af maksimalt $170 \mathrm{~cm}$. Murene var 110-120 $\mathrm{cm}$ brede og opbygget af kampesten samt røde munkesten. Mod vest, ca. $5 \mathrm{~m}$ fra SV-hjørnet, har der været en knap $3 \mathrm{~m}$ bred falset portåbning. Der er registreret $i$ alt fem vinduesåbninger i huset: tre i den nordlige del af vestmuren samt to i sydgavlen. Der var i alle tilfælde tale om smigede vinduesåbninger med en indvendig bredde på $85 \mathrm{~cm}$. Der blev ikke registreret spor efter hverken dør- eller vinduesåbninger i syd- og østmuren. De oprindelige terrænforhold omkring bygningen kendes ikke, men det faktum, at to af ydermurene er uden spor af vinduer, kunne antyde en vis højdeforskel, således at dele af bygningen har været gravet ind i en skrænt eller lignende.

Der blev gravet fem steder ved ruinen. Vinkelret på vestmuren i flugt med døråbningens nordside blev der iagttaget resterne af et smalt, ca. 50 $\mathrm{cm}$ bredt, fundament (fig. 29). Det er uvist, om man fandt fundamentets vestlige afslutning, eller om udgravningen blev stoppet af andre årsager. Der blev tilsyneladende ikke registreret andre fundamentsforløb eller gulvlag i tilknytning hertil.

Udgravningerne inde i selve bygningen gav øjensynligt ikke noget resultat, idet man ikke gravede til undergrund.

Vi står overfor kælderetagen af et større stenhus. Størrelsesmæssigt kan huset måle sig med Sønderhuset på Tjele, med hvilket også vinduesåbningerne har store ligheder.

Det er uklart, hvad det fundne fundament repræsenterer. Den mest sandsynlige tolkning synes dog at være, at der er tale om fundamentet til en trappe eller et galleri, som har ledt op til etagen ovenover. Under alle omstændigheder viser fundamentets ringe bredde, at der ikke er tale om en bygning af samme dimensioner som stenhuset.

Der blev ikke gjort nogen daterende fund i forbindelse med udgravningerne af stenhuset, men på grundlag af husets lighed med andre stenbyggede huse som fx Tjele og Østergård, må man formode en datering omkring 1500.

Forbindelsen mellem Testrup hospital og Testrupgård er ikke klar. Det må dog formodes, at Testrupgårds jorder har udgjort grundlaget for driften af hospitalet, og at gården dermed har haft funktion af ladegård, og selve stenhuset har en sådan karakter, at det kan have været bispens bolig, når han var på stedet. I efterreformatorisk tid har flere konger gjort ophold i Testrup på deres rejser rundt i landet, og de kan ligeledes have opholdt sig i stenhuset i Testrup. ${ }^{30}$ Testrupgård må altså således formodes at have været en del af hospitalets gods og administration, men samtidig kan det også have været del af den stiftslige administration, således som traditionen foreskriver. 

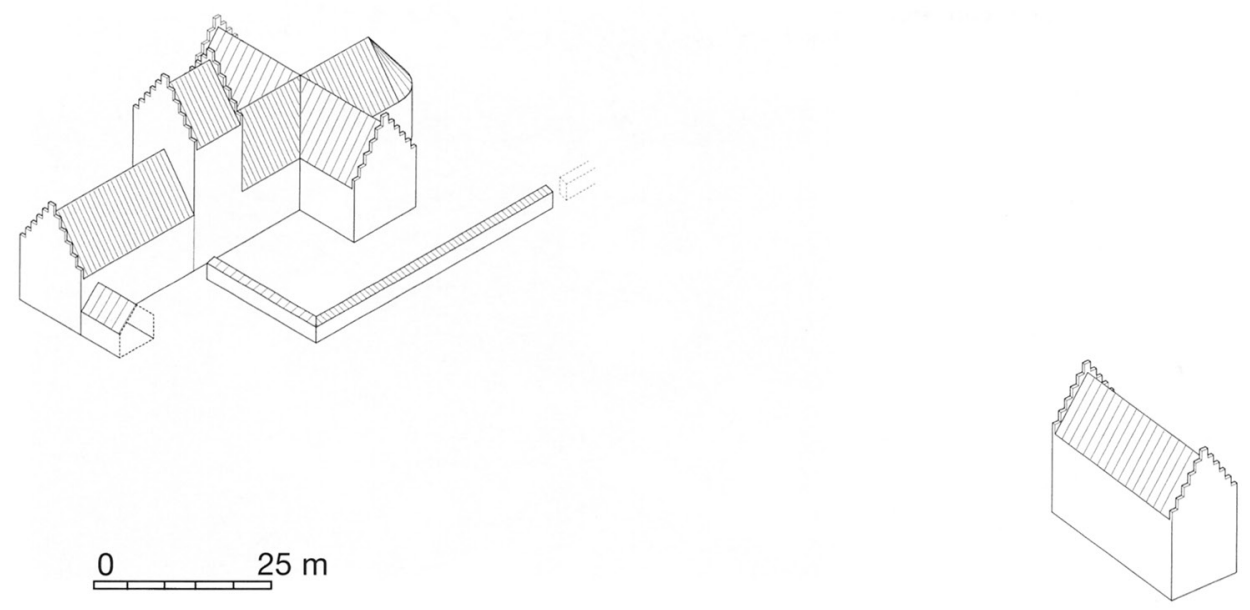

Fig. 30. Rekonstruktion af Testrup kirke og hospital samt Testrup Stenhus o. 1500. Rekonstruktion: Ann Bodilsen; streg: Kis Bodilsen.

A reconstruction of Testrup Church and Hospital and Testrup Stenhus at c 1500. Reconstructed by Ann Bodilsen. Drawn by Kis Bodilsen.

\section{Sammenfatning}

Undersøgelserne af Testrup kirke og hospital er et eksempel på, at arkæologi og historie sammen har givet et klarere billede af stedets udseende og dets funktion i middelalderen samt hvilke ændringer, der kom til efter reformationen (fig. 30).

Nationalmuseets undersøgelser i 1980 viste, at der forud for hospitalsbyggeriet lå en traditionel kvaderstenskirke bestående af kor og skib på stedet. Denne kirke blev revet ned, og i stedet blev der opført en gotisk korskirke med en hospitalsbygning bygget direkte på vestenden af kirken. Fra de skriftlige kilder ved vi, at Viborgbispen stifter et hospital i 1432, og det må formodes, at byggeriet af kirken er påbegyndt omkring dette tidspunkt; hverken kirkens planløsning eller arkitektur strider imod denne opfattelse. 1439 bliver kirken indviet, men om hospitalsbygningen har stået færdig på dette tidspunkt er uvist. Det virker dog rimeligt, da der bag stiftelsen i 1432 må have været tale om én samlet godsdonation.

Vi kan kun gisne om, hvad godsdonationen har omfattet, men sandsynligvis har Testrupgård med tilliggender udgjort en væsentlig del af 
Fig. 31. Helligkilden Sankt Søren er beliggende nordøst for Testrup hospital på en mindre bakkeskråning. De nuværende ejere af Testrupgård har lagt sten $\mathrm{i}$ den nu næsten udtørrede helligkilde, så vandet synes tydeligere. Foto: Betty Laustsen.

The sacred spring of St. Severinus is situated NE of Testrup Hospital on a sloping hillside. Nowadays, the spring has almost dried out, and the present owners of Testrupgård have put stones in the spring

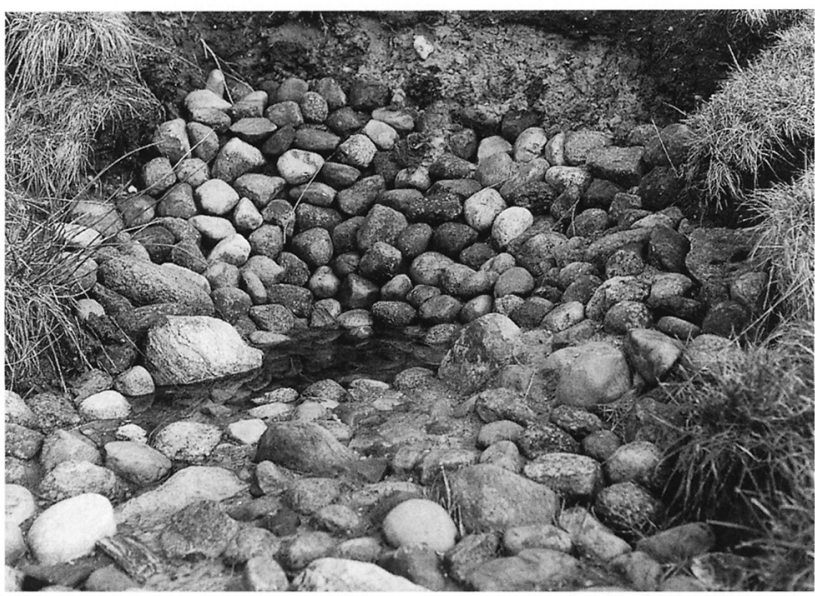
to accentuate the water. Photo: Betty Laustsen.

grundlaget for oprettelsen af hospitalet. Da hospitalet oprettes af Viborgbispen synes det rimeligt at anse Testrupgård som en del af bispegodset.

Den gotiske korskirke har været ca. 35,5 m lang inkl. tårnet og $9 \mathrm{~m}$ bred; ved korsarmene dog $25 \mathrm{~m}$ bred. Størrelsesmæessigt er der altså tale om en ganske anseelig kirke, som sagtens kan stå mål med flere af de kendte valfartskirker som fx Karup, Kliplev, Holmstrup og Kippinge.

Det synes derfor rimeligt at antage, at Testrup i lighed med disse kirker har været genstand for en betydelig valfart, og her må helligkilden Skt. Søren have spillet en ikke uvæsentlig rolle (fig. 31). Ingen af disse formodninger kan dog bekræftes i det skriftlige kildemateriale.

Forudsætningerne for hospitalsbyggeriet synes således at skulle findes i senmiddelalderens stærke frygt for fortabelse og ønsket om frelse, hvor læren om skærsilden samt muligheden for at afkorte opholdet her ved udøvelsen af gode gerninger, bodsrejser og afladshandlinger har været væsentlig for både stedets åndelige og ikke mindst økonomiske berettigelse.

Hospitalsbygningen, som er bygget i direkte vestlig forlængelse af kirken, er en 16,5 $\mathrm{m}$ lang og $9 \mathrm{~m}$ bred bygning og sandsynligvis i to stokværk. De arkæologiske undersøgelser viser, at den nederste etage oprindeligt var indrettet som et stort rum, en overhvælvet sygesal. En tilsvarende indretning ses i den bevarede sygesal i helligåndsklosteret i København. I København er der gemmenicher i væggene til patienternes ejendele. Om noget sådant har været tilfældet i Testrup er uvist, da der ikke er bevaret tilstrækkeligt murværk, til at de kan påvises. 
Hvordan hospitalet i Testrup i øvrigt har været indrettet, vides ikke. Et generelt træk i datidens hospitaler var dog, at der stod et alter i østenden af sygesalen, da den lægelige omsorg i middelalderen ikke kun omfattede kroppen, men også sjælen. ${ }^{31}$ Ved at have et alter i østenden af sygesalen kunne også de sengeliggende patienter deltage i messen. Og på samme måde må vi forestille os, at det var i Testrup.

Rent størrelsesmæssigt er hospitalsbygningen i København langt større end Testrup, men sammenlignet med de bevarede hospitalsbygninger ved fx Skt. Hans Kloster i Odense samt karmelitterhospitalet i Helsingør er der ganske gode overensstemmelser. ${ }^{32}$

Det er vanskeligt at finde danske paralleller til kombinationen valfartskirke og hospital, som vi har det i Testrup.Vi har kendskab til en hel del hospitaler i middelalderen, men der er i alle tilfælde tale om hospitaler i et klostermæssigt regi. Ved valfartskirken Vor Frue i Karup synes der dog at have været et lignende anlæg. Som udgangspunkt er der begge steder tale om almindelige sognekirker, som i senmiddelalderen bliver revet ned, og på stedet opføres store gotiske kirker, som făr tilbygget et hospital. Begge steder ligger kirke og hospital tæt på en helligkilde, således at vi må forestille os, at valfarten og de tilknyttede markeder har været en væsentlig indtægtskilde med interesse for både verdslige og gejstlige magthavere. ${ }^{33}$ Rent historisk har vi langt det største kendskab til Vor Frue i Karup. Her ved vi, at kirken var en stor valfartskirke ikke alene p.g.a. helligkilden, men også p.g.a. den grædende Madonna, som fandtes i kirken.

Hospitaler bygget $\mathrm{i}$ forlængelse af en kirke kendes flere steder fra i Europa, og der findes også anlæg, som minder en del om Testrup, bl.a. Ingolstadt i Tyskland, hvor helligåndshospitalet var bygget i forlængelse af en sogne- og valfartskirke. ${ }^{34}$

Hvilken type hospital har der så været tale om i Testrup, og kan det overhovedet sættes i relation til nogle af de gængse typer, vi normalt taler om i middelaldersammenhæng? Hospitalet kan uden tvivl betegnes som et helligåndshus, idet betegnelsen $\mathrm{i}$ almindelighed blev benyttet om steder, som gav sig af med pleje og pasning af syge og fattige. ${ }^{35}$ Hospitalet i Testrup er imidlertid ikke kendt fra de skriftlige kilder som et helligåndshus, og vi ved ikke, hvorledes hospitalet i Testrup var organiseret, og om man i lighed med helligåndshuset i fx Aalborg fulgte et klart regelsæt.Vi ved, at hospitalet blev styret af en gejstlig forstander, men hvem der passede de syge, hvor de boede, og hvilken tilknytning hospitalet havde til bispesædet, ved vi ikke. Økonomien må hovedsageligt have været baseret på almisser og indtæegter fra helligkilden og valfarten, ligesom selve godsdriften må have bidraget væsentligt til økonomien.

De helligåndshuse, vi har kendskab til fra de skriftlige kilder, ligger alle 
uden undtagelse i byerne, ${ }^{36}$ men til forskel fra disse almindeligt kendte helligåndshuse er hospitalerne i Testrup og Karup beliggende på landet. Hospitalerne i Testrup og Karup er indtil videre enestående i Danmark, men muligheden for, at der har eksisteret lignende anlæg andre steder i landet, er oplagt til stede. Flere af de kapeller og store stenhuse, vi har kendskab til rundt omkring i landskabet, kunne sagtens have været hospitaler. Rent bygningsmæssigt adskiller en hospitalsbygning sig ikke fra andre bygninger, og har stedet ikke fundet plads i nogle af vores bevarede skriftlige kilder, så vil det være næsten umuligt at påvise en hospitalsfunktion, medmindre et skeletmateriale viser tydelige sygdomsspor, der entydigt peger i den retning.

\section{NOTER}

1) Trabjerg 1993.

2) Bl.a. Wammen 1911, Andersen 1959 og Smidt 1917.

3) Matthiessen 1933, s. 40 og $47 f$.

4) Som note 3 .

5) DiplVib, nr. 405, s. 321f.

6) Se fx Pontoppidan 1768, s. 695.

7) DaBrev, s 466.

8) Pontoppidan 1768. Det fremgår flere steder af Pontoppidans tekst, at han har læst Kristen Sørensen Testrups beskrivelse af Testrup i Rinds Herreds Krønike, men KST nævner ikke dokumentet, som Pontoppidan altså selv må have set/læst. Senere omtales dokumentet af flere andre forfattere, som sandsynligvis har deres oplysninger fra Pontoppidan. M.h.t. om dokumentet forsat eksisterer, skal det bemærkes, at det kun er eftersøgt i publicerede kildesamlinger, og der foreligger altså den mulighed, at dokumentet fortsat er bevaret, men ikke registreret i nogle af kildeudgivelserne. Det er dog værd at bemærke, at det ikke er medtaget i DiplVib.

9) DiplVib, nr. 36, s. 25. Kilden er dateret 1436, men årstallet kan ikke være rigtigt, idet Torlav først bliver bisp i 1438. Skt. Katarina blev i senmiddelalderen regnet til blandt nødhjælperne, som var en gruppe af 14 helgener, som blev anset for at have en særlig evne til at beskytte mod alle slags sygdomme, skaffe et rimeligt levned samt sikre en god død. Hun afbildes med sværd og marterhjul som sine kendetegn.

10) Testamente fra 1508. DiplVib, s. 357. Kilden er ikke gengivet, men kun refereret, og det kan derfor ikke afgøres, om der i teksten står, at gaven er til kirken Skt. Søren; der kunne jo også være tale om en gave til hospitalet, som i lighed med helligkilden kunne være viet til Skt. Søren. KST nævner, at altertavlen på højalteret var viet til både Skt. Karen og Skt. Søren. Denne altertavle brændte i 1698 . Testrup 1867, s. 348.

11) Testrup 1867, s. 370. Wiberg 1870-71, s. 448.

12) Testrup 1867, s. 348. Pontoppidan 1768, s. 695.

13) Jf. note 10 vedr. omtalen af altertavlen.

14) DiplVib, nr. 314, s. 245f. Viborg hospital bliver stiftet i 1541. Se Ursin 1841, s. 251.

15) KST og med ham flere andre fortæller, at der blev flyttet to klokker fra Testrup, men i kilden står der, at det drejer sig om den største klokke fra Testrup. Derudover får Viborg Domkirke to klokker fra Vestervig, og måske er det her, tingene blandes sammen. KancBrevb 1566-70, s. 214. Da Domkirken i 1726 igen brændte, gik klokkerne endnu engang tabt, og dermed også klokken fra Testrup.

16) S. Nygård 1904-05, s. 96. Pontoppidan 1768, s. 656.

17) Undersøgelserne blev foretaget af Birgit Als Hansen og Morten Aaman Sørensen. Beretning findes i Nationalmuseets beretningsarkiv med journalnummer 128/82-j 29/3. 
18) Udgravningerne blev foretaget i følgende perioder: 6.7.-6.11.1981; 2.8.-26.11.1982; 5.4.27.6.1983. Fra udgravningslederens side foreligger der kun en beretning fra det forste års udgravning. I 1995 skrev undertegnede beretning på alle udgravningerne. Sagen har journalnummer VSM 882D Testrup.

19) Som note 17.

20) Møller 1961, s. 265-266. Bertelsen 1998, s. 295-301.

21) Teglstenene i portens mure er dels gule, dels mere teglrøde end de røde sten i hospitalets ydermure. Størrelsesmæssigt er teglstenene, som er anvendt i porten, af et mere kvadratisk tværsnit og lidt kortere.

22) Meddelt i brev fra Jørgen Steen Jensen af 11. november 1982. FB 3865;VSM 882D39.

23) Ud fra fotomaterialet synes det som om, der kan føjes yderligere en fase til hospitalets bygningshistorie, idet der på flere dias kan ses en række store syldsten i begge portåbninger $\mathrm{i}$ et niveau over brolægningen og de oprindelige fundamentssten. Det ser altså ud til, at portåbningen atter er blevet tilmuret. Det er ikke muligt ud fra de omtalte dias at datere denne evt. tilmuring.

24) Becher 1813, s. 226-227, 308-310.

25) Journalnummer AS 19/82.

26) Pia Bennike personlig meddelelse.

27) Pia Bennike og Anna-Elisabeth Brade 1999, s. 63.

28) Testrup 1868 , s. 349.

29) Frilægningen af stenhuset fremgår af et brev fra herredsfogeden i Rinds-Gislum herred dateret 15. november 1861. Brevet samt svaret findes i korrespondancearkivet i Antikvarisk-Topografisk Arkiv på Nationalmuseet. Fredningsnr. 1610:132.

30) Matthiessen 1933.

31) Da sygdom i middelalderen opfattedes som en straf fra Gud, anså man det for vigtigere at kurere sjælen end kroppen, og den officielle lægekunst var derfor rettet mod medicin og terapi.

32) Odense: $17 \times 7,8 \mathrm{~m}$. Helsingør: $15,5 \times 7 \mathrm{~m}$.

33) Hospitalet i Karup er rent bygningsmæssigt så godt som ukendt, men det formodes at have ligget nord for kirken.

34) Craemer 1963. Jetter 1973. Specielt med henblik på Ingolstadt se Craemer, s. $72 f$.

35) Trabjerg 1993, s. 63.

36) Trabjerg 1993, s. 135.

* Manuskriptet til denne artikel er udarbejdet med støtte fra Det Arkæologiske Nævn.

\section{LITTERATUR}

Als Hansen, Birgit og Morten Aaman Sørensen 1981: Kirkerne i Testrup. Viborg Stifts Årbog 1981, s. 70-75.

Andersen, Vald. 1959: Karup kirke. Arhus Stifts Årboger bd. 51-52, s. 191-208.

Becher, Ignatius 1813: Farstrup og Axelsons dagboger fra det 16., 17. og 18. århundrede. Aalborg. Historisk Samfund for Himmerland og Kjær Herred har genudgivet den i fotografisk optryk i 1987.

Bennike, Pia 1999: Facts or myths? A re-evaluation of cases of diagnosed tuberculosis in the past in Denmark. G. Palfi et al. (red.): Tuberculosis. Past and Present, s. 511-518.

Beretning på Nationalmuseet j.nr. 128/82-j 29/3.

Beretning på Viborg Stiftsmuseum j.nr.VSM 882D Testrup.

Bertelsen, Thomas 1998: Kirketage - Danske kirkers tagbeklædning i middelalderen. Kuml 199798, s. 295-346.

Craemer, Ulrich 1963: Das Hospital als Bautyp des Mittelalters. Köln.

DiplVib $=$ Diplomatarium Vibergense. Breve og Aktstykker fra ældre viborgske Arkiver til Viborg Bys og Stifts Historie 1200-1559. Udg. A. Heise. Kjøbenhavn 1879.

DaBrev $=$ Fortegnelser over Danmarks Breve fra Middelalderen med udtog af de hidtil utrykte. 1.rk. 4. Udg. Kr. Erslev. 1906-12. 
Jetter, Dieter 1973: Grundzïge der Hospitalsgeschichte. I)amnstadt.

KancBrevb = Kancellicts Brevbeger vedrerende Danmarks inder Forhold 1551-. I: Uddrag udgivne af Rigsarkivet. Kobenhavn 1885.

Matthiessen, Hugo 1933: Viborg-veje. Kobenhavn.

Moller, Elna 1961: Den middelalderlige kirke som byggeplads. Fortid og Nutid XXI, s. 26()-273.

Nygård, S. 19()4-(15: Biskop Soren Lintrups visitatsbog. Sal linger til Jjdsk Historic og Topografi. 3. rk. 4. bd.

Pontoppidan, Erich 1768: Den Danske Atlas. Kiobenhavn.

Rapport ved Balslev Jorgensen vedr. skeletmaterialet j.nr. AS 19/82.

Smidt, C.M. 1917: Karup og dets Helligkilde. Sxrtryk af Samlinger til Jydsk Historie og Topografi 1917.

Testrup, Kristen Sorensen 1867: Rinds Herreds Kronike. Udgivet af (). Nielsen i Samlinger til Jydsk Historic og Topografi. 4. hefte. Aalborg 1867.

Trabjerg, Lis 1993: Middelalderens hospitaler i Dammark. Hojbjerg.

Ursin, M.R. 1849: Stiffsstaden Viborg. Kjobenhavn.

Wammen, J.P. 1911 (genoptrykt 1965): Karup. Dens kirke og dens helligkilde.

Wiberg, S.V. 187()-71: Almindelig Dansk Prastehistoric. Bd. 1-4.

\section{Testrup Church and Hospital}

The present appearance of Testrup Church, which is situated on a hill north of Testrupgård farm and west of the village of Testrup in Himmerland, is that of a small nave church. Nowadays, Testrup is a remote village, but during the late Middle Ages it was a well-attended place of pilgrimage, centrally situated in the diocese of Viborg and close to the main road from Viborg to Aalborg (fig. 1). At that time, the church was a large Gothic church with transepts and added hospital. According to tradition, the bishop had a farm in the vicinity, which functioned as a centre of church administration. A spring dedicated to the holy Severinus (in 1)anish, St. Søren) lay near by. Annual markets were held here.

The first written source mentioning Testrup is from 1432. This document has vanished, but Pontoppidan's Den Danske Atlas from 1763-81 informs us of its content. According to this, Bishop Herman of Viborg founded a hospital in Testrup. Testrup is mentioned again in a written source from 1439, this time telling that Bishop Torlav consecrated the church to St. Catherine.

After the Reformation, the hospital went to the king. It finctioned as a hospital until
1545, when King Christian III donated the farm of Testrupgard and its lands to the hospital in Viborg, which had been founded in 1541. Testrup Hospital was then closed down, and the church began to fall into decay.

In 1699, Testrupgård Farm was sold, and it has been in private ownership since then. The hospital and the western end of the church were presumably demolished in 1748 (fig.2.).

In 198(), the National Museum examined the church in connection with a restoration project, and several areas inside and outside the church were excavated. The results inspired an excavation campaign in 1981-83, during which the rest of the church and the hospital area were investigated (fig. 3). The main purpose of the investigation was to decide the layout of the buildings in the late medieval phase. Today, Testrup Church appears as a 23.5-metres long nave ending in a semicircular apse. The walls are built of large medieval bricks and boulders and rest on a plinth of Romanesque granite ashlars. In the western end, a church entrance opens into a vaulted vestibule (fig. 4).

In 198(), the investigations showed the 
remains of an older, Romanesque village church underneath the present church. The older church consisted of a nave and a chancel. The ashlars of the present church and some Romanesque ashlars at Testrupgård must come from this older church, the size and appearance of which seems to have resembled other ashlar churches in the area (fig. 5).

The 1981-83-investigation, which included almost the entire west end of the church, showed that the church was originally eleven metres longer and had been constructed as a double wall, mainly built of bricks, with a filled-in cavity and resting on a boulder foundation. The masonry had been whitewashed inside and outside (figs. 6-7).

Three openings were registered in the western end of the church (fig. 8). The doors to the North and South are original, and people thus had access to the church through the tower. Whether the third door in the west gable was original is difficult to establish.

The remains of the bottom step of a spiral staircase was found in the NW corner of the tower (fig. 9), as was the remains of a brick floor covering large parts of the western end of the church. Under this floor, three lead pits were registered. Their positions closely resemble the positions of lead pits found in other medieval churches.

In 1981, the northern transept was partly excavated, and to judge from the boulder foundations, the transept was nine metres wide and eight metres long (fig. 11). The construction of the foundations corresponded to that of the rest of the foundations. No masonry was preserved.

Graves were found in all the excavated areas of the transept. They were interpreted as belonging to the oldest church, as the foundations for the transept had disturbed several of them. Only two graves were excavated, and none of them contained skeletal material.

A small part of the eastern wall of the southern transept was excavated during the church restoration in 198(). A ground survey using spits showed that the dimensions of the southern transept resembled those of the northern transept.
The excavation of the hospital went on from 1980 to 1982 . At first, only minor areas were excavated, but eventually the hospital was completely excavated, as was a small building with a baking oven built onto the hospital on the northern side (figs. 3 and 12).

Originally, the hospital was one large building, supposedly with two floors, the lower one of which was vaulted (fig. 2()). A passageway was made through the hospital sometime or other, and on its northern side, a building with a large baking oven was erected (figs. 15, 17, 21-22). These changes probably took place simultaneously and according to an overall plan, as the walls of the passage and those of the building with the oven are bonded (fig. 16). The changes of the buildings are difficult to date, but the fact that the openings of the passage were built without a rabbet suggests that the changes took place after the Reformation - perhaps in connection with the closing of the hospital in 1545. The changes altered the layout of the building and turned it into an up-todate dwelling, perhaps for a vicar?

The excavation also resulted in the unearthing of a 7()$-\mathrm{cm}$ wide foundation running north-south by the southwestern corner of the hospital (fig. 23). To register more of this building, and other possible buildings, several minor excavations were carried out in the churchyard. The foundation was traced another 5.7 metres from the corner of the hospital. However, the end of it was not established. Although no foundation was established towards the East, this wall sequence is interpreted as part of a southern wing.

Several excavations south of the east end of the hospital, between the hospital and the church, were carried out to establish a possible original four-wing layout. Here, a strong boulder foundation running $\mathrm{N}-\mathrm{S}$ was found. It turned east $\mathrm{c} 18$ metres south of the church and ended in line with the eastern end of the church (fig. 21).

However, as no foundation parallel to this was found, the structure should probably be interpreted as a support for a strong dike or wall. Perhaps it originates from a churchyard enclosure, as graves were only found east of the hospital.

Thirteen skeletons were found in the 
floor of the tower and sent to the anthropological laboratory at Copenhagen University for investigation (fig. 25). Two of the skeletons, that of a 1()-year-old child and that of an 18-year-old woman had bone changes due to tuberculoses (figs. 26-27). Only (), $1 \%$ of the skeletons excavated in Denmark have signs of tuberculoses, so two out of thirteen skeletons in Testrup showing this disease is a high amount. Although thirteen is a small number for statistics, it is striking that such a large part of skeletons showing diseases are found in connection with a hospital.

East of Testrupgard and SSW of the church is the ruin of a large stone house, "Testrup Stenhus", which was unearthed in c 186() and scheduled as a historical monument in 1943. In 1982, a survey was made of this ruin, and also elevations of its inner walls (fig. 28). The walls were built of boulders and large medieval bricks and were preserved in a width of 1.1-1.2 metres and in a height of up to 1.7 metres. Towards the west was a door opening with a rabbet. Three window openings were registered in the northern part of the western wall, and two in the southern gable. As two outer walls bear no traces of windows, the building is thought to have been built into a slope.

The remains of a $\mathrm{c} 5()-\mathrm{cm}$ wide foundation at right angles to the western wall and in line with the northern side of the door was probably the base of a staircase or gallery leading to the upper floor (fig. 29). Although the excavation revealed no dating finds, the size of the house and the similarities with other brick-built houses such as the manors of Tjele and $\oslash$ stergård suggest that it was built around 15()().

The connection between the hospital and Testrupgaird is unknown. However, as Testrupgard is supposed to have provided the basis for the hospital services, the farm may have functioned as a bailey. Perhaps the bishop stayed here periodically, and the king might have stopped off here on his travels after the Reformation.

The combination of archaeology and history has given a better understanding of the layout of this building complex and its functions in the Middle Ages, and of the structural changes following the Reformation (fig. 3()).

The Gothic church had a length of $\mathrm{c} 35$ metres, tower inclusive, and width of nine metres with a 25-metres wide transept. This large church bears comparison with the pilgrim churches of Karup, Kliplev, Holmstrup, and Kippinge. Like these, Testrup presumably was the object of considerable pilgrimage. The sacred spring of St. Severinus probably added to its popularity, although the written sources do not mention this (fig. 31).

The fear of perdition, which prevailed in the late Middle Ages, and the wish for a shorter stay in the Purgatory, which led to the exertion of good deeds, penance and sale and purchase of indulgences, probably formed the spiritual and economical basis for the institutions at Testrup.

The hospital, which was built as an extension of the church towards the West, is a 16.5-metres long and 9-metres wide building, probably with two storeys. It is much smaller than the "Helligåndshus" (House of the Holy Spirit) in Copenhagen, but is the size of the Skt. Hans Kloster (St. John's Monastery) in Odense and the Karmelitterhospital (Carmelites' Hospital) in Helsingor. The bottom storey was a vaulted room firnished as a hall for the sick, as is the case with the preserved hall for the sick in the Helligandshuset. Whether it had wall recesses for storing the patients' belongings, as in Copenhagen, cannot be determined.

We know of some medieval hospitals connected to monasteries. However, I)anish parallels to the combination of pilgrim church and hospital in Testrup are rare. One other example, which combines pilgrim church, hospital, and sacred spring, is the Frue Kirke (the Church of Our Lady) in Karup. This combination occurs elsewhere in Europe, for instance at Ingolstad in Germany.

The hospital in Testrup was no doubt a hospital for the sick and the poor, although the written sources contain no reference to this. Also, the organisation of the hospital whether, for instance, a certain set of rules were followed - is obscure. We know that 
the hospital was led by a clerical principal, but who looked after the sick, and where the staff lived is unknown. Also, we do not know how the hospital was connected to the diocese. The economy was probably partly based on charity and money coming from the sacred spring and the pilgrims, and partly based on the estate.

All the hospitals known from the written sources were in a town. The hospitals at $\mathrm{Ka}-$ rup and Testrup lie in the country. So far, these two institutions are unique in this respect. Still, other similar institutions may have existed elsewhere in the country. Perhaps some large chapels and large stone buildings in the countryside were hospitals. However, as the layout of a hospital does not differ from that of other buildings, only skeletal material found in connection with the building and carrying distinct traces of diseases will reveal a possible hospital function.

Ann Bodilsen Viborg Stiftsmuseum

Translated by Annette Lerclie Trolle 
